\title{
Architecture from the 1920's in a Block of Avenida São João
}

\author{
By Regina Helena Vieira Santos*
}

\begin{abstract}
This article is about the architecture developed on a fragment in the old city center of São Paulo, Brazil. After in-depth research about a small extension of Avenida São João, it was realized that a volumetric unit of buildings was in two blocks near Vale of Anhangabaú. As a result of the first modern urban intervention in the city in 1912, and according to the law that determined the extension of the old street, (Rua) São Joa became Avenida São João, and all primitive buildings were demolished to reconstruct new eclectic constructions. These reconstructions were designed by important architects and engineers working around the town in the 1920s. To know the city's architecture many original documents were investigated, such as drawings and projects in the Historical Archive of São Paulo. They are the basis for writing this text, complemented by the studied iconography, historic cartography and some laws of the occasion that allowed this urban work of great impact in the city. Currently, the research focuses on two blocks with five eclectic buildings built on each one. These buildings have good designs that survived the new demolitions of the 1950s and so on. The architecture recorded in documents deals with the memory of a city that no longer exists, the city built in the 1920s and soon thereafter. A proposed urban environment was disintegrated in time. This reveals that the city of São Paulo is always vulnerable to losing collective urban memory, which warns us about the importance of protecting the remaining assets. This material can be useful for future restoration and conservation projects of these buildings.
\end{abstract}

\section{Introduction}

The main research presents a small part of the urban history of the city of São Paulo, Brazil, through the architecture of certain buildings that show little persistence and many transformations over time. ${ }^{1}$ For this article, a block was selected that, due to the first modern urban intervention in the city, demolished the primitive constructions of the even side of the road, to receive those buildings constructed in the decades 1910/1920. These are the buildings that survive presently, perhaps because they are preserved by legislation regarding cultural heritage safeguards.

The law ${ }^{2}$ that approved the enlargement was published in 1912 and transformed a city that was until then quiet, small and poor. The primitive buildings on the old street (Rua) São João were expropriated, then demolished, to the Avenue São João opening with 30 meters width and in the new alignment were erected new buildings.

\footnotetext{
${ }^{*}$ Professor, University of Sao Paulo, Brazil.

1. The main research is available at: http://bit.ly/2E4HmDl.

2. Law n. 1596/1912, “Approva a planta do alargamento da rua S. João, desde a praça Antonio Prado até a rua Lopes de Oliveira" [Approvement of the enlargement plan of S. João Street, from the Antonio Prado Square to Lopes de Oliveira Street] (sic.).
} 
When studying the urban history of São Paulo, it is inevitable to use some bibliographical sources, such as the classic works of architect Benedito Lima de Toledo, "São Paulo, três cidades em um século" and "Anhangabaú". Or the publications of sociologist professor Nestor Goulart Reis Filho as "São Paulo Vila Cidade Metrópole". In addition, not least the published researches of teacher architect Carlos A. C. Lemos, among which "Alvenaria Burguesa" or "Cozinhas, etc." or "A República ensina a morar melhor."3

The temporal cut for this work extends from 1889 to 1930, an era known as the First Republic in Brazil. This was a period with important social and economic transformations in the country. Consequently, physical transformations also occurred, such as those in São João Street and its adjacent areas.

The methodology adopted began with the realization of the inventory ${ }^{4}$ of real estate concerning existing buildings in the research area. After the summary table was completed, the inventory form of each property was made. Continuing the research was essential to understanding the material, primary source, existing in the Historical Archive São Paulo - AHSP. This material consists of the projects or reform requests made by citizens in the past. Thus, we present how the architecture buildings developed, thereby making it possible to know architectural characteristics, years of the requests, and the completion terms. In view of this, it was verified the relevance of the enlargement of the street São João in Avenue, with the buildings in the new alignment and new height, according to the enacted law: with more than three floors; however, following the Code of Postures $(1875 / 1886)$ in force at the time. The study was complemented with iconography, historic cartography, and legislation of the occasion.

The research works with the constructed environment and the record of its transformations in the fabric and the urban landscape of a region in the city of São Paulo. From the existing physical space, certain elements of the old urban design were was rescued. The investigation concerns a fragment of Avenue São João, that begins in the current Praça Antonio Prado (primitive Largo do Rosário) to the crossroads with Avenue Ipiranga (old Rua Ypiranga). The public and private works participated in this transformation of a small area of the city's urban fabric, and in a short period: "Street (Rua) São João, the paulistano ${ }^{5}$ Boulevard ${ }^{6}$ of the First Republic (1889-1930)".

The research structure for this investigation has three parts. In the first part, we contextualize the Street (Rua) São João in the urban history of São Paulo. We revisited the exit routes of this center and the expansion of the urban network. We retraced the transition from the axis of occupation: starting from the east,

3. Carlos A. C. Lemos, A República ensina a morar (melhor) (São Paulo: HUCITEC, 1999); Lemos, Alvenaria Burguesa (São Paulo: Nobel, 1989); Lemos, Cozinhas, etc. (São Paulo: Perspectiva, 1976).

4. São Paulo (SP). Secretaria Municipal de Cultura. Departamento do Patrimônio Histórico. IGEPAC-SP: Inventário geral do patrimônio artístico e cultural de São Paulo (Banco de dados) (São Paulo: DPH, 2012). Inventory is available at: http://bit.ly/2nz05xt.

5. Paulistano means from São Paulo city.

6. This is the title of the Doctoral Thesis. The french word boulevard, was borrowed because the translation itself is the definition that best fits to the work done at the beginning of the 20th century. 
via Rio Tamanduateí, moving to the north, with the stations of the railway lines, and due to the changes in the economy, later to the west, with the valorization of the occupation of the Anhangabaú riverside border.

In the second part, we studied the Street (Rua) São João based on primary documentation from the consulted collections, such as the collections of private works and public works belonging to the Historical Archive of São Paulo (AHSP). We also compared these with the cartographic bases and the iconographic registers. This information was fundamental to clarifying the puzzle of São Paulo, which no longer exists as it was. Through these means, we know of the house of the family Souza Barros, built at the end of the eighteenth century, as well as the American School, on the corner of Rua Ypiranga. At the base of the slope, the São João Market, neighbor to the site that belonged to Companhia Antarctica, where the Polytheama space operated, followed by Teatro Eldorado, Casino Paulista, Bijou Theatro and Bijou Hall. Further up, the building built in 1895 was the seat of the Steinway Hall, which after reform became the Panorama Hotel, and which from 1909 was the headquarters of the Musical and Dramatic Conservatory of São Paulo.

We also investigated a little about the Largo do Rosário, which housed the eighteenth-century pylon clay church of the Brotherhood Nossa Senhora do Rosário dos Homens Negros. The church was demolished for the accomplishment of the first modern urban work in the city, the opening of Antônio Prado Square. The Martinico Prado Building (present building of the BM \& F, Commodities and Futures Exchange) was built in 1906 at this location. The Brotherhood also built its new Church of the Rosario on the land granted to it in Largo do Paissandú. Nearby, at number 115 Rua São João, the Carlos Gomes Theater was also built in 1906. These buildings elucidate that the area of study, already at the end of the 19th century and beginning of the twentieth, had a relevant cultural character in the city. To close this part, a chapter is given on the dwellings in this street from 1906 to 1910.

In the third part, we examine the "Boulevard" São João and its new eclectic buildings. We began with a chapter on the "urban plans" for the city presented in 1910/11 that resulted in the decision of the enlargement work on Street São João. This includes an aspect of urban controversy, with urban projects starting from Adolpho Augusto Pinto's proposal in 1890 and others from the Councilor Augusto Carlos da Silva Telles in 1906. Then, the three plans of 1910/11 were proposed: one by Alexandre Albuquerque (from Chamber and capitalists), another by engineers Victor Freire and Eugênio Guilhem (from the City Hall), and the third by Samuel da Neves (from the State). At the end is the report of the architect Joseph-Antoine Bouvard. It is clear that the ideas on the occasion were similar, and gradually they were maturing, but the engineer Pinto, who was given continuity by Freire, finishing with the landscaping of Bouvard, determined the north for the politic decision. It was opportune when studying the projects to meet professional engineers and architects, among them by Francisco Ramos de Azevedo and Ricardo Severo. The importance of the formation of the school of Paula Souza and the Polytechnic Faculty of São Paulo was observed.

The next chapter is presented in order to study the new buildings. The 
buildings on the even side of the street were all expropriated, when they were not from the municipality. They were demolished for the extension of 30 meters of the carriage way. The new constructions of the even side were made in the new alignment, meeting the new building rules. The first building was the "Dom José" built in 1913.

In 1915/16, on the corner of Largo Paissandú was built the edifice "Cotonificio Paulista". Two neighboring buildings in this same block were completed in 1918 and 1920, "Hotel Central" and "Hotel Britania", respectively. Next to these, the "Correio Building" was inaugurated in 1922. The three projects are from the Ramos de Azevedo Technical Office. The lot that was missing in this block was completed only in 1928, with the "Oscar Rodrigues Building", which even has two more floors than the others do.

Neighbouring the "Dom José" building, in the lot that belonged to the Souza Queiroz family, the building "Cinelândia Hotel" was built in 1924. In that block, the "Columbia Palace Hotel" was completed in 1920. And on the corner of Avenida Ipiranga, signed by the architect Ricardo Severo, a small building dates to 1922.

In the quarter of Ladeira (slope) São João, on the corner of Rua (street) Líbero Badaró, dates from 1920 the building "Casa Dhélomme". On the other corner, with the Vale of Anhangabaú, designed by the architect Ricardo Severo, the building "Baraúna" dates from 1923. In the old number 14, the building dates 1925. In the old number 12, signed as interested Luiz Asson for the owner José Pucci, the building was built in 1926. Closing this block in the lot, building number 12A was completed in 1936. These five buildings are highlighted in this article.

However, new constructions were also executed on the odd side. In the land belonging to the Antarctica Company, in 1914/16, the Antarctica Casino was built, which later became the Edifice of Fiscal Police. Some requests were made for several buildings in 1920. About the building on the odd corner of Street Líbero Badaró, no drawings were found, but based on the available images, this building is also from the beginning of the 1920s. On the corner with Ipiranga Avenue, the building Zico and its neighbor, were built in 1924. The following year, the Albuquerque \& Longo firm, built an edifice numbered 85 . The edifice by the number 123 dates from 1926/27. Finally, the skyscraper of the Martinelli building was inaugurated in 1929. Closing this part, a chapter analyzes this urban work as the first "boom" of construction in the city of São Paulo.

The rapid population growth of Sao Paulo has always been remarkable during the period discussed. External factors certainly influenced this, such as the great immigration of Europeans to the country. Leonardo Benevolo, architect and historian, in his classic work "The History of the City", reveals the environment of the European cities after the Industrial Revolution. Because of the decrease in mortality, there was population growth in the cities, associated with the redistribution of the population, the migration process from the countryside to the city, and complemented by the development of communications, improvements in roads, waterways and, from 1825 , with the presence of the railway. Added to this fact are the particularities of each country bringing large-scale immigration to 
São Paulo, such as Italian unification.

The enormous population growth caused unprecedented consequences in the calm São Paulo of the mid-nineteenth century. Associated with this, the country experienced changes in social relations, with the end of slave labor, and political change with the establishment of the Republic. The city of São Paulo was economically privileged with the economic warming of coffee exports, known as "green gold". The combination of these factors allowed the great physical transformation in the territory of old Piratininga. ${ }^{7}$

A major contribution to these changes was the presence of railway stations in the city at the end of the 19th century and at least three railroads were crossing the urban fabric. Nowadays, at the beginning of the 21st century, it is regrettable that the railway network that connects the capital with other cities in the state has been abandoned. Instead of expanding and taking advantage of transport on the rails to connect great distances, we find part of this heritage deteriorating.

Another instigated fact to do this research was the iconography of Street São João, which became São João Avenue (Figure 19). Consequently, it was made the analysis of historical cartography and the study of architectural projects of buildings. In this way, the three pillars (documents, cartography and iconography) that support the doctors' investigation became known.

The study focuses on a volumetric unit of buildings in two blocks near Vale of Anhangabaú. Those two blocks have ten eclectic buildings. The research focuses on digital surveys with 3D scanners to develop a front conservation plan for those buildings. Also using this technology, one building, the Edifice Baraúna, was elected to receive an architectural restoration and conservation project.

This article is important for future studies because the focus is on one of those two blocks (Figure 1). This block is known also as Ladeira (slope) São João, it has five ecletic buildings: "Casa Dhelomè"; "antique number 14"; "Edifice Baraúna"; "antique number 12" and "antique number 12A". It is a part of the Avenue São João fragment studied, and it goes from the corner with street Libero Badaró until the Vale do Anhangabaú.

7. Piratininga is an old way of referring to the city of São Paulo. 


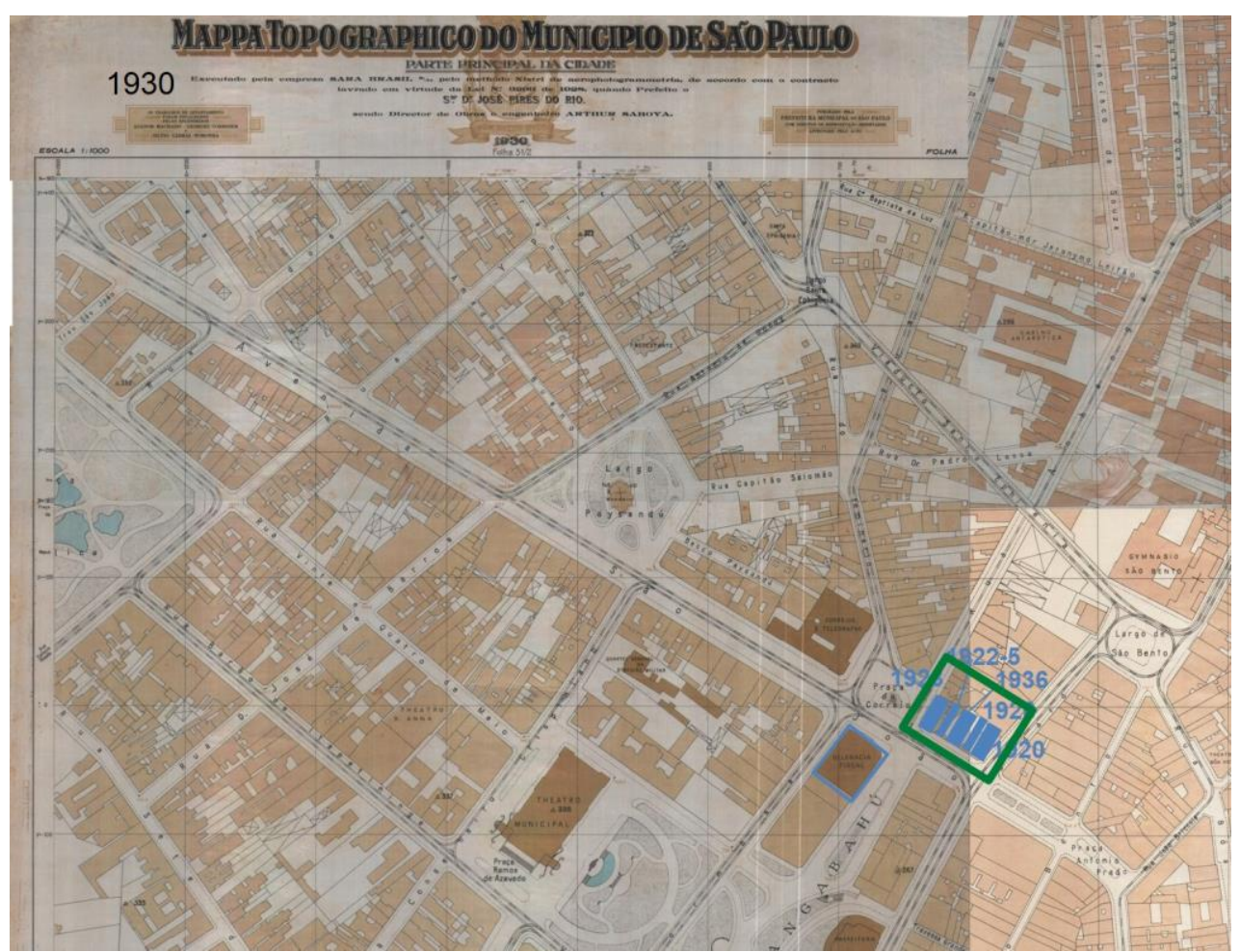

Figure 1. In the detail of the Plant, SARA BRASIL from 1930, the Area of this Study is Marked in Green, and in Blue the Five Buildings

Source: Collection of the D.P.H. - Departamento do Patrimônio Histórico of São Paulo.

\section{The Block with Five Buildings}

The doctoral research a fragment of the old Street (Rua) São João, from the former Largo do Rosário (present Antônio Prado Square), until the intersection with the old Street (Rua) Ypiranga (current Ipiranga Avenue). It was realized that a volumetric unit of buildings was in two blocks near Vale of Anhangabaú. Each one with five buildings, officially by the municipality, they are blocks 058 and 061. These ten eclectic buildings were built as a consequence of the 1912 enlargement law of Street São João, that is, they were designed on the new alignment, following the new height standards, developed by the important architects and engineers who worked in the city in that time. This article will deal with the block known as "Ladeira (slope) São João" (Figure 2), with five constructions, among them one designed by the Portuguese engineer Ricardo Severo, and another by the Ramos de Azevedo Office. 


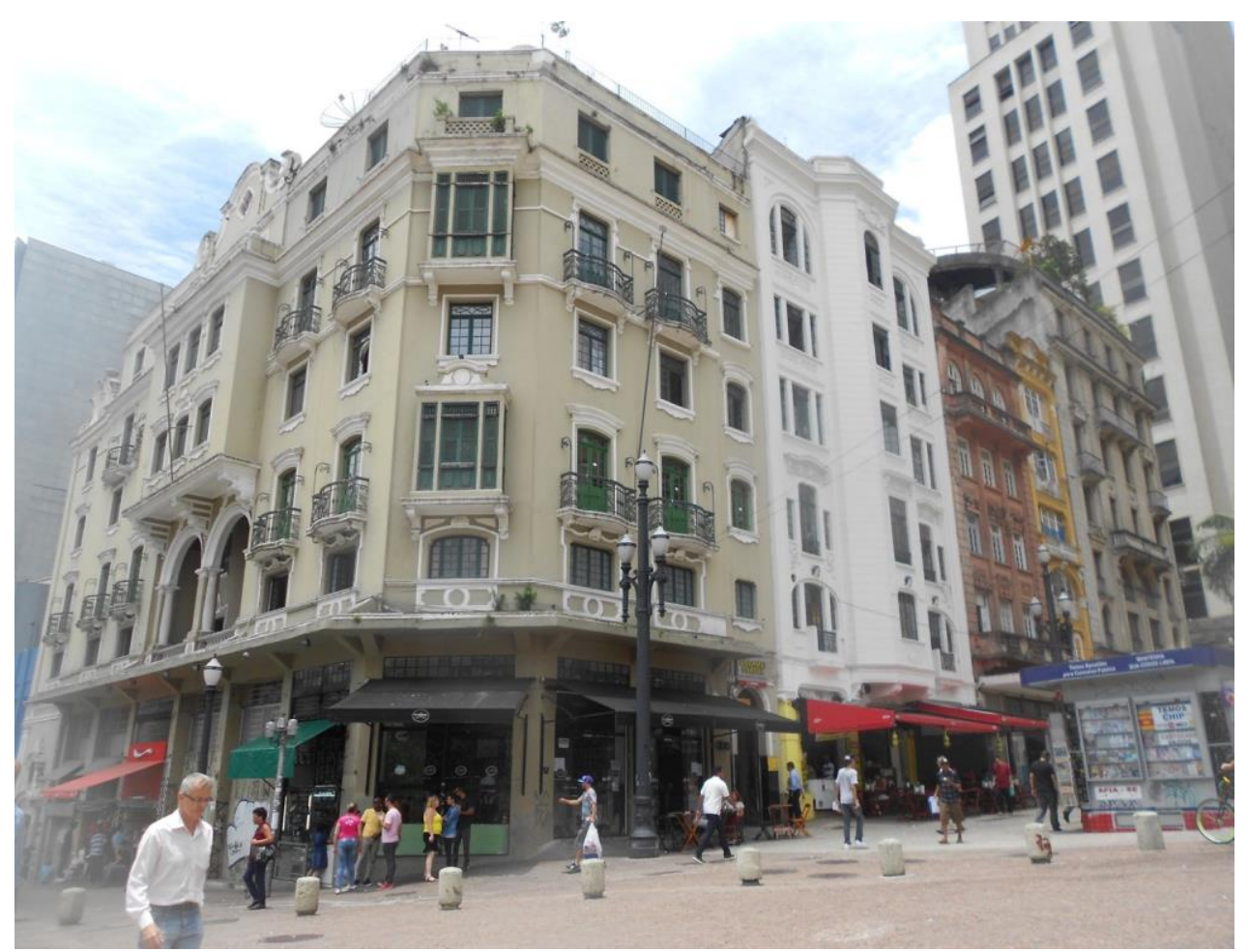

Figure 2. View of the Façade Block, with the Five Eclectic Buildings

Source: Author's Photo, 2016.

\section{Edifice "Casa Dhelomè", 1920 (Figures 3, 4 and 5)}

In the block, also known as Ladeira São João, the lot on the side even that is on the corner of Street Líbero Badaró, after expropriation, became the property of Mr. Daniel Dhélomme.

The owner, in 1920, requested the construction of the "Casa Dhélomme", at Avenida São João, number 12T (current 98), which would have four warehouses on the ground floor and on the other floors office rooms. With two facades, the project and construction was the responsibility of the Escritório Técnico Companhia Iniciadora Predial.

The building has six floors with two solar facades: one turned to Street Libero Badaró and another to Avenue São João, they are connected on the corner with a chamfer inclined at $45^{\circ}$.

The main access is through the Líbero Badaró Street, to the vertical distribution hall with two elevators beside the stairs; a pediment tops the façade, and the door is made of iron in artistic locksmith and glass. This axis of access has a different treatment in the facade, the row of windows is arranged with a difference of the alignment of the other floors, and between the fifth and sixth floor is finished with a round arch. From this axis to the facade facing Street Líbero Badaró, the layout of the windows marks a different pace, with three rows to the right and one to the left. This is all in tune with the corner and the other façade as well. 
This block with facade to the avenue, including the chamfer, has a set of balconies between the second and third floors, fourth and fifth floors that give a slight movement to eclectic facade. Some have a balustrade, while others are cast in iron with artistic locksmiths. Between the third and fourth floors, among the axes of the frames, there are decorated ornaments and motifs. In the second floor, some windows have a triangular counterpane as a pediment, while in the fourth floor some windows have a segmental arch. Between the fifth and sixth floor there is continuous entablature, the row windows on the sixth floor are all with straight arches, on the roof there is terrace, and currently heliport.

The building has artificial stone rendering; and the frames are made of wood and glass. It is characterized, very well maintained, and overall, has been well restored.

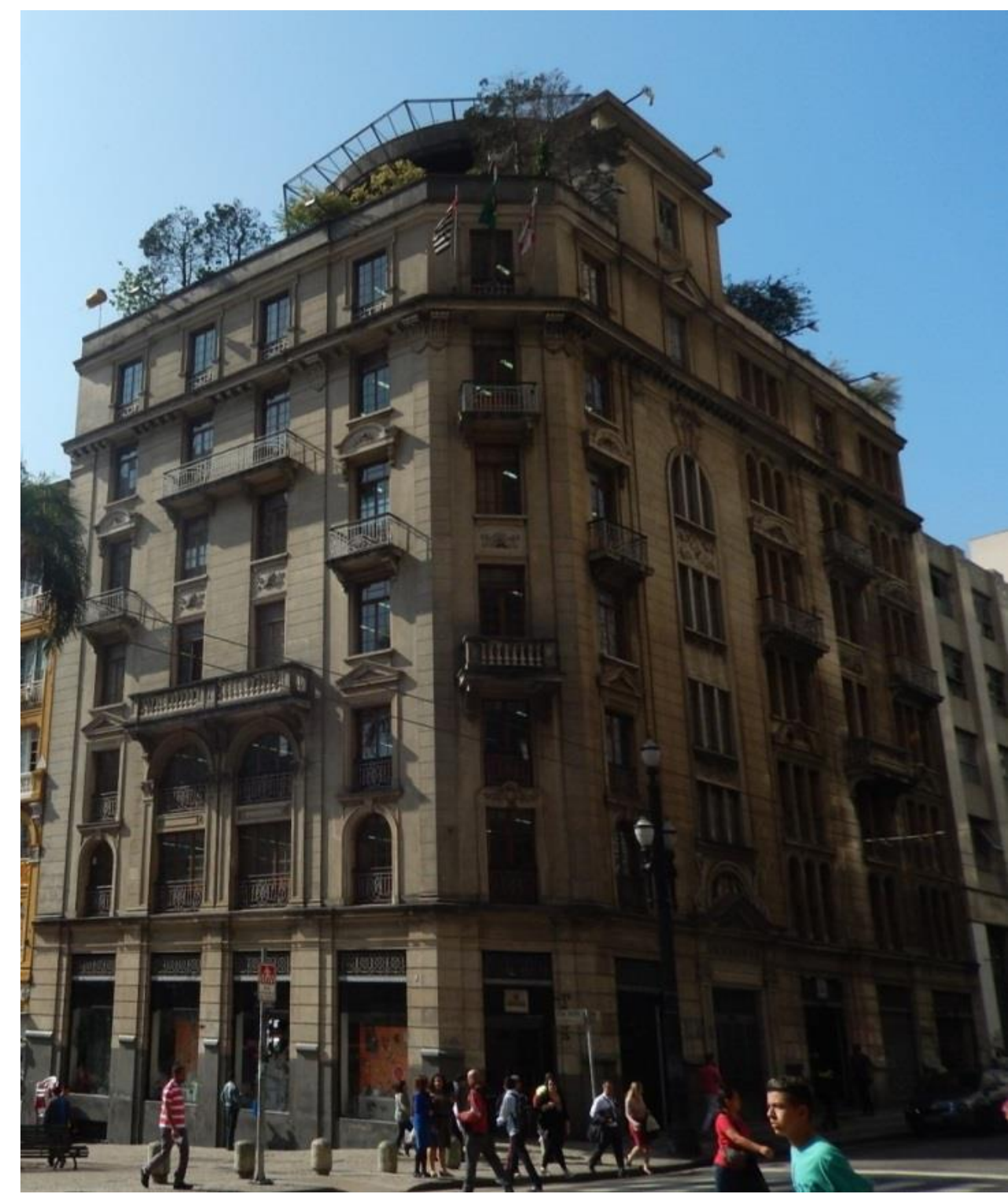

Figure 3. Facade of the Building "Casa Dhélomme"

Source: Author's Photo, 2016. 


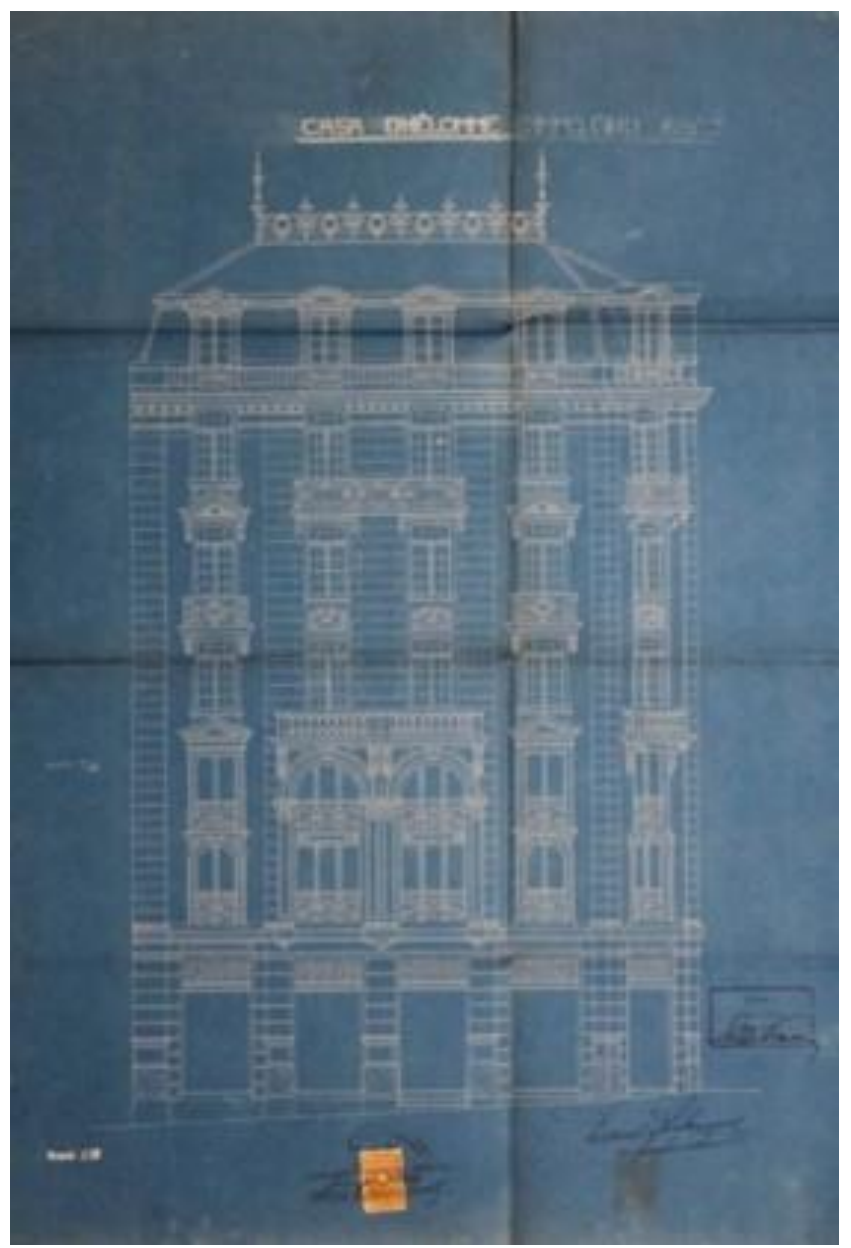

Figure 4. Drawing of the Facade of the Building "Casa Dhélomme" Source: Original Drawings, 1920, from the Arquivo Histórico São Paulo - AHSP.

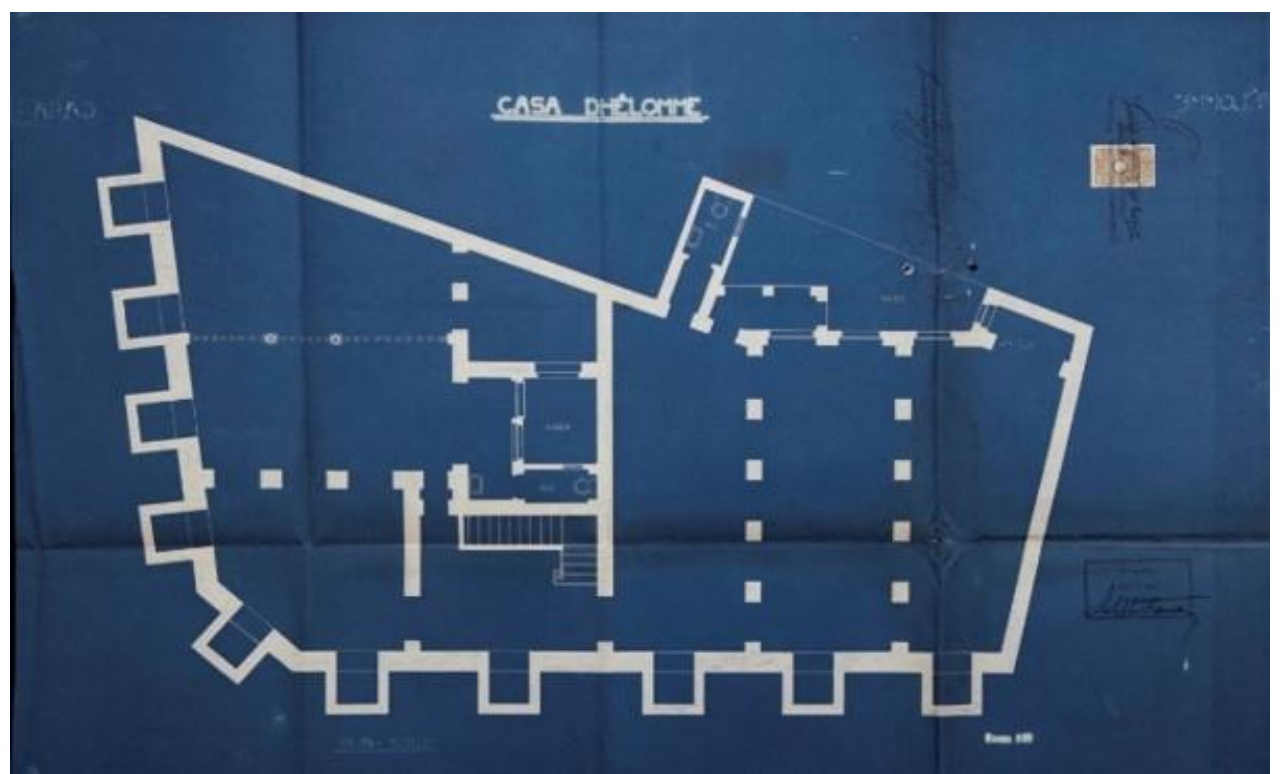

Figure 5. Drawing of the Basement Plan of the Building "Casa Dhélomme" Source: Original Drawings, 1920, from the Arquivo Histórico São Paulo - AHSP. 


\section{Edifice Antique Number 14, 1922/25 (Figures 6 and 7)}

Resulting from expropriations for the enlargement of Street (Rua) São João, the lot with a plan in the form of a scalene triangle, owned by Daniel Dhelomme, in 1922, under the office Engenheiros Architectos F. P. Ramos de Azevedo \& C. ${ }^{\text {a }}$ requested:

"The undersigned, in charge of the construction of a building at Av. São João in the lot located at 11.50 of the building on the corner of Rua Libero Badaró (side pair of both public roads) according to the plants, cuts and memorial together require Your Excellency the necessary building permit ${ }^{\prime \prime}$ (sic).

In addition to the drawings, the descriptive memorial includes:

"Building with basement, ground floor, over-store and 2 floors as indicated on the plants, cuts and facades together. The over-floor and floors extend into bay window satisfying arts. 89 and following from the current Municipal Standard. The architecture of the facade could not satisfy in total the paragraph 2th. of art. 100 due to the strong slope of the section of the Avenue, which prevents the concordance of the horizontal lines, while observing what the letter (b) of the same paragraph prescribes. The structure of the building will be reinforced concrete with walls in brick masonry. Floor of sanitary cabinets in ceramic tile. Tile bars with 1.50 high in the walls of the same. Roof in galvanized sheet. Gutters and conductors of the same material. Frames with glass in all openings" ${ }^{\prime \prime}$ (sic). 


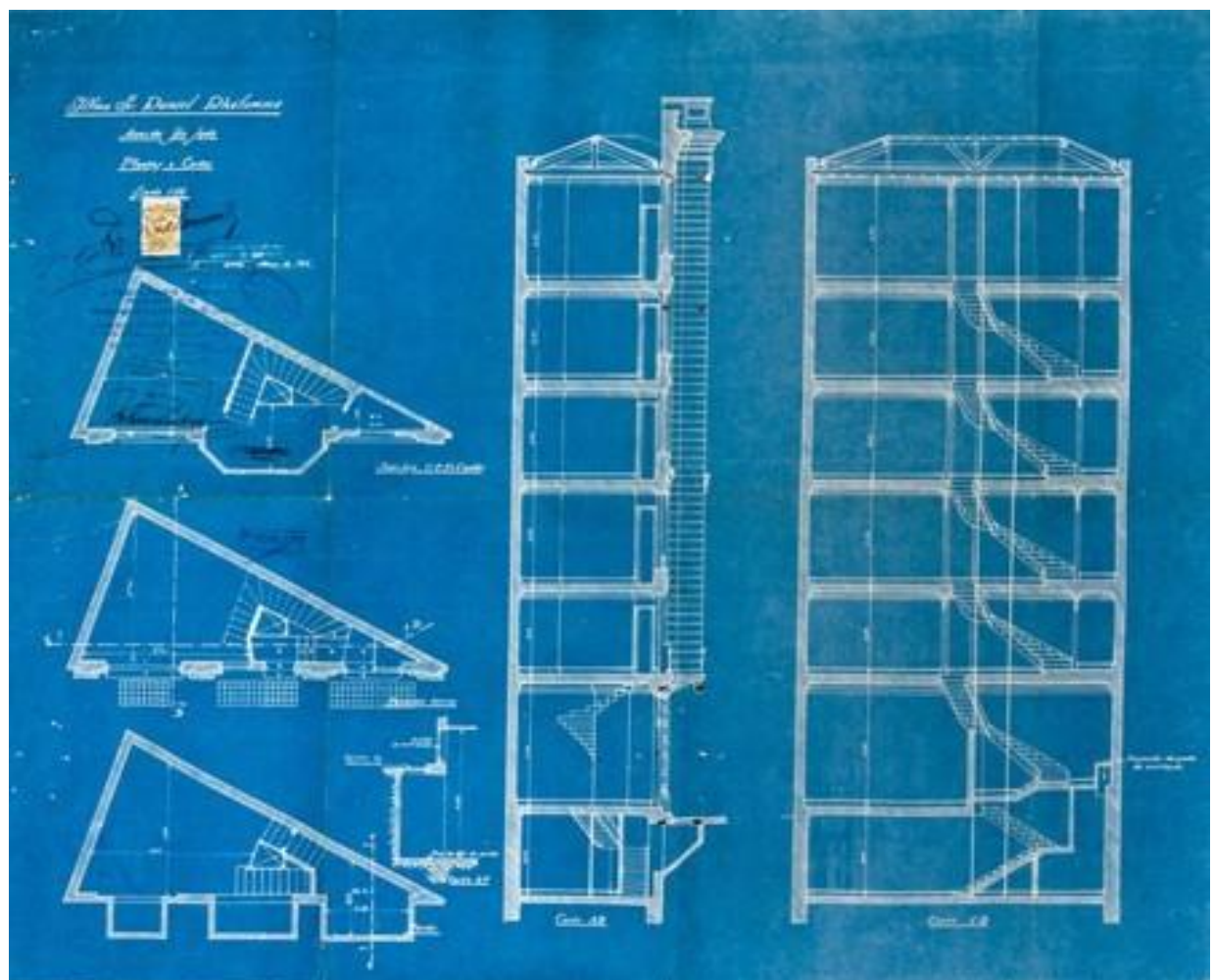

Figure 6. Drawings of the Plants and Sections of the Building "Antique Number 14 "

Source: Original drawings, 1922, from the Arquivo Histórico São Paulo - AHSP.

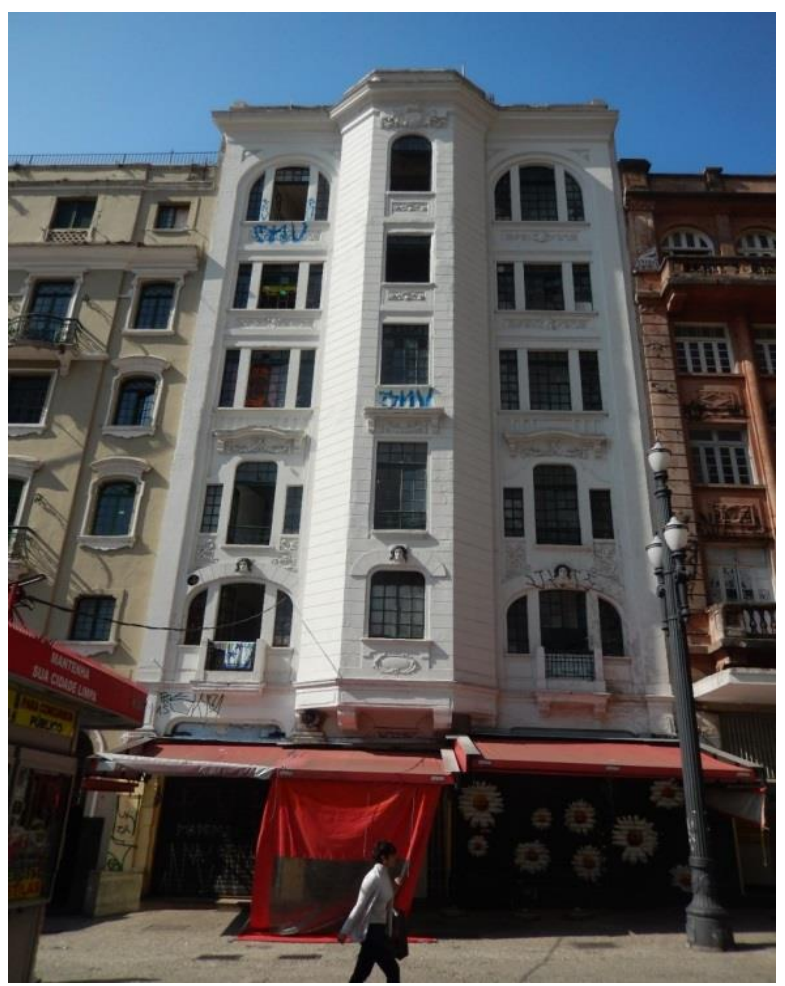

Figure 7. Facade of Antique Number 14

Source: Author's Photo, 2016. 
Studying the drawings, we read in the plans and sections the distribution of the vertical circulation located in the narrowest part of the triangle. The sides of the triangle measure: to the front $12.20 \mathrm{~m}$; to the left $5.80 \mathrm{~m}$ and to the right $11.80 \mathrm{~m}$. The first project presented had a basement, ground floor, overstore, and two more floor types; the project actually executed has four floor types.

The ground floor has a commercial establishment, and access to the basement and upper floors in the center. From the overstore to the fourth floor the result of the bay window on the facade became elegant, in addition to having greatly improved the vertical circulation. All floors have only one office, with the floor area around $45 \mathrm{~m}^{2}$.

The facade has an eclectic symmetrical composition with a prominence on the central axis of the bay-window, and on each side one additional row of windows, with three openings that have diverse compositions, and all are sealed with glass window frames. Among the pavements are various decorations with differentiated themes. Crowning the building is the entablement and the brick border.

It was completed in 1925, it has artificial stone rendering. Currently its architectural and decorative features are preserved, though poorly preserved, with slight decharacterizations.

Edifício “Baraúna”, 1923 (Figures 8, 9 and 10)

In 1923, signed by the architect Ricardo Severo there is the request:

"The undersigned, having to construct for the Santa Casa de Misericórdia of the Capital a building of loft, located to the Avenida São João, on the corner of the Post' square, is going to submit the appreciation of Your Excellency the drawings of plants, facades and sections requesting the necessary permit license, as well as scaffolding license in the extension of $9.00 \mathrm{mts}$. In the Avenida S. João, 3.50 on the corner and 31.10 in the Post' Square. In these terms. P. Deferment"10 (sic).

10. AHSP, OPA_cx 141 S7, 1923, drawings included. 


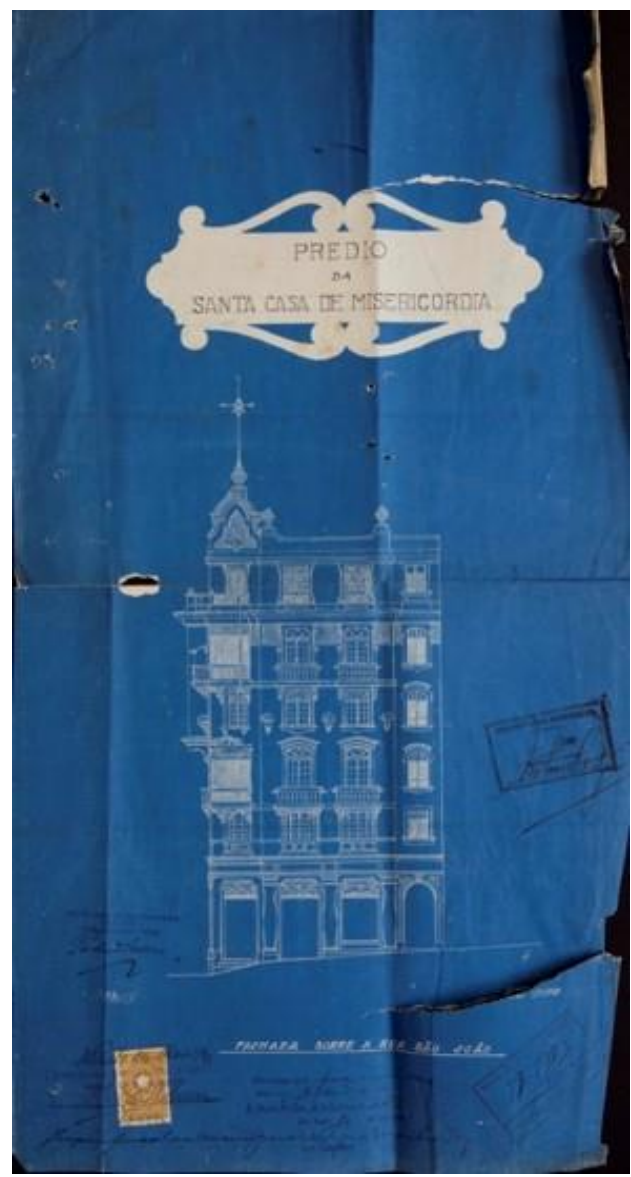

Figure 8. Drawing of the Facade of the Edifice "Barauna"

Source: Original drawings, 1923, from the Arquivo Histórico São Paulo - AHSP.

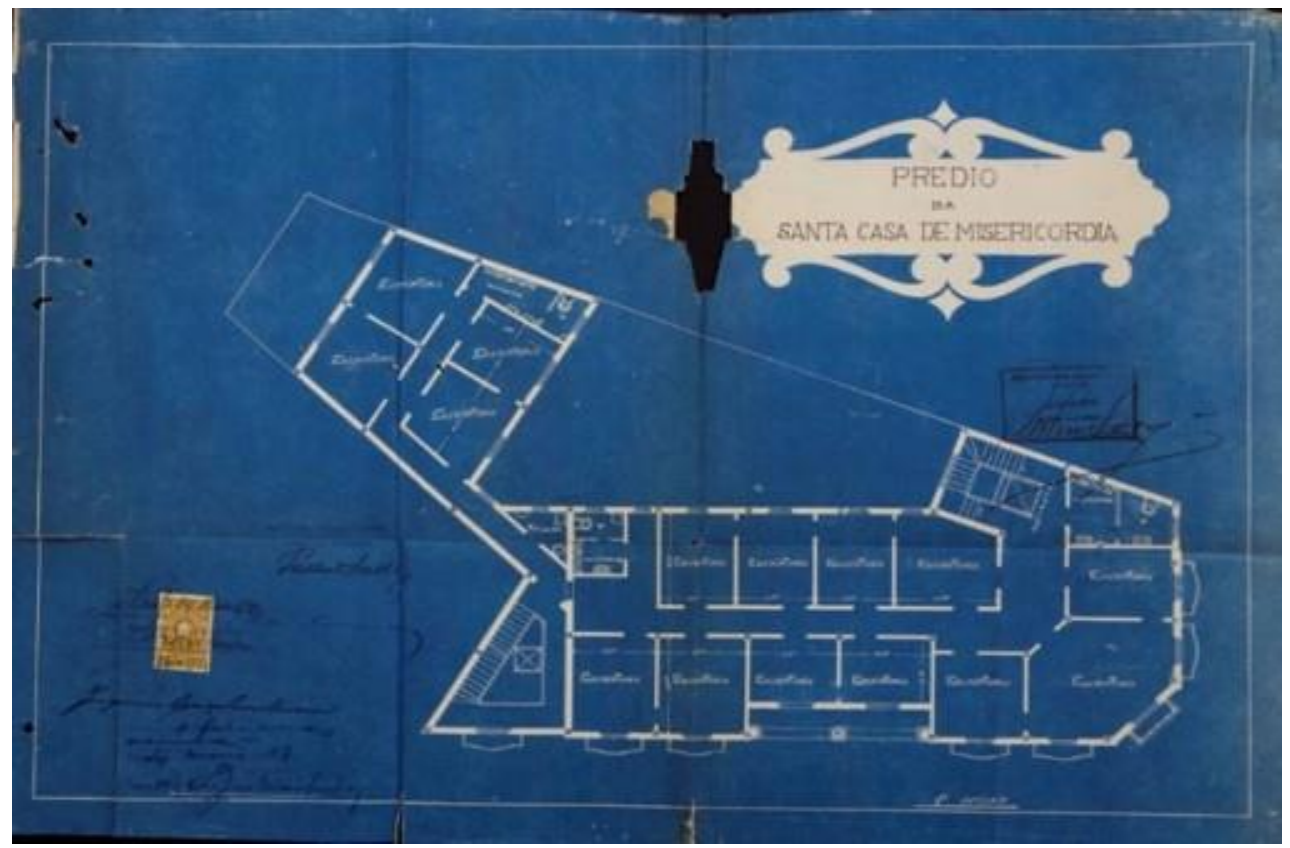

Figure 9. Drawing of the Old First Floor Plan of the Edifice "Barauna" Source: Original drawings, 1923, from the Arquivo Histórico São Paulo - AHSP. 
Called "Baraúna Edifice", it was built in reinforced concrete and brick masonry, coated with scraped mortar (artificial stone). The frames are made of wood and glass. The ground floor is all commercial, considering the basement that results from the topography faced to the Vale of Anhangabaú

As result of the drawings presented to the municipal concession, the project presented occupied a lot of singular form, and its edifice has five floors more ground floor building. It has two sun facades, one to the avenue and the other to the square. The first one has three opening axes with one on the right of the entrance to the stairwell; the second is composed of six opening axes and two large central ones simulate a loggia on the first floor. The axis of symmetry was accentuated by the presence of a crowning pediment. The two facades are connected by a corner solution inclined to $45^{\circ}$ consisting of a single axis of openings with a pediment as a crown flanked by two pillars. On the left lower body, with a single axis of openings and crowned by pediment with ornate, constitute the second body access staircases of the building (to the Vale do Anhangabaú).

Studying the original plans, the vertical circulation is solved with two independent accesses, one by Avenue São João, number 16 (currently 126) and the other by Vale do Anhangabaú (currently Avenue Prestes Maia, boardwalk area), both are at the border of the building with the neighboring building.

For air ventilation and lighting of all rooms, there is an inner courtyard. The stairs access the basement, which is a large single space. The floor rez do chão considers the access quota for Avenida São João. Designed to be a warehouse, Guanabara Restaurant has been there for many years. The overstore floor has office rooms, bathrooms, "loggia", and interesting is the spelling "ascensor" to the elevator. The first floor has a plan equal to the overstore floor. On the second floor, the rooms are for table games, billiards, one of them measuring $8.00 \mathrm{~m}$ by $5.60 \mathrm{~m}$ with the denomination "baccarat", and in the rooms facing the Avenue, "restaurant", "buffet", besides the "cosinha" and "toillete" and "wc" (sic.). ${ }^{12}$ On the third floor, near the access to the Avenue, there is the distribution hall for bathrooms, a room for the wardrobe, another room facing the chamfer, and a large hall with a stage that accesses the terrace that cover part of the building. The attic makes a double foyer to the lounge, providing a countertop facing the stage; besides bathroom, a room for secretary and another for the management (on the chamfer).

The front composition is neo-colonial, ${ }^{13}$ remembering that the edifice is on the corner, there are three facades. The basement rooms are all for commerce.

11. The word "ascensor" is elevator in Italian. It means that who had drawn it, probably is some Italian immigrant that was working in the Severo's office in São Paulo.

12. Baccarat is an Italian game with casino cards. The spellings are enclosed in quotation marks because they are found in the drawings.

13. According to the Dicionário da Arquitetura Brasileira, de Corona \& Lemos, p. 337, Neocolonial was the artistic movement that aimed at the renaissance and the respective stylization of the architectural features of the Brazilian constructions of the time of the Colony. Among the forerunners is the Portuguese architect Ricardo Severo. From this movement, the taste for theoretical studies continued, it did not perpetuate the desire for a new Brazilian architecture, very nostalgic and not rational. 
The first opening, on the right of who looks from Avenue São João, has access to the upper floors, and the door is with round arch. The other access is on the left axis of the building in the facade to the Vale of Anhangabaú; it also has a door with round arch and is decorated. Between the ground floor and the overstore floor, there is continuous entablature distinguishing the basement from the body. On the overstore between the windows and the entablature, there are decorative details. In the first and third floor on the chamfer, there is a presence of muxarabis in wood. Some of the openings have bodyguard in iron with artistic locksmith. Frames are made of wood and glass. Between the third and fourth floors, there is a simple continuous entablature. The fourth floor (attic) has a smaller built area then the others, due to the retreat to the interior of the lot, which is used as a terrace. In this floor, the windows and the small balcony have counters with small arches superimposed that are considered a characteristic detail of the neo-colonial style. ${ }^{14}$

The crowning is with entablement and brick border, the chamfer has a differentiated finish on it. In the central axis of the Vale of Anhangabaú façade, there is an outstanding pediment adorned with volutes. This axis corresponds to the span of the "loggia" on the overstore and first floors.

The Portuguese architect Ricardo Severo ${ }^{15}$ was a theorist and practitioner of the neo-colonial style in Brazil, who created many projects both for commercial purposes and residential elite.

14. Reis Filho and Nestor Goulart. São Paulo Vila Cidade Metrópole (São Paulo: Takano Editora Gráfica, 2004), 82. Detail probably created and used by the architect Victor Dubugras, which can be considered as a typical element of the Neocolonial.

15. Ricardo Severo da Fonseca Costa was born in 1869 in the city of Lisbon, in 1890 he graduated in Civil Engineering from Public Works, and the following year in Civil Engineering from Minas, both at the Polytechnic Academy of Porto. About this professional read: Joana Mello, Ricardo Severo: da arqueologia portuguesa à arquitetura brasileira (São Paulo: AnnablumeFapesp, 2007); Maria Lúcia Bressan Pinheiro, Neocolonial, Modernismo e Preservação do Patrimônio no Debate Cultural dos Anos 1920 no Brasil (São Paulo: EDUSP/Fapesp, 2011). 


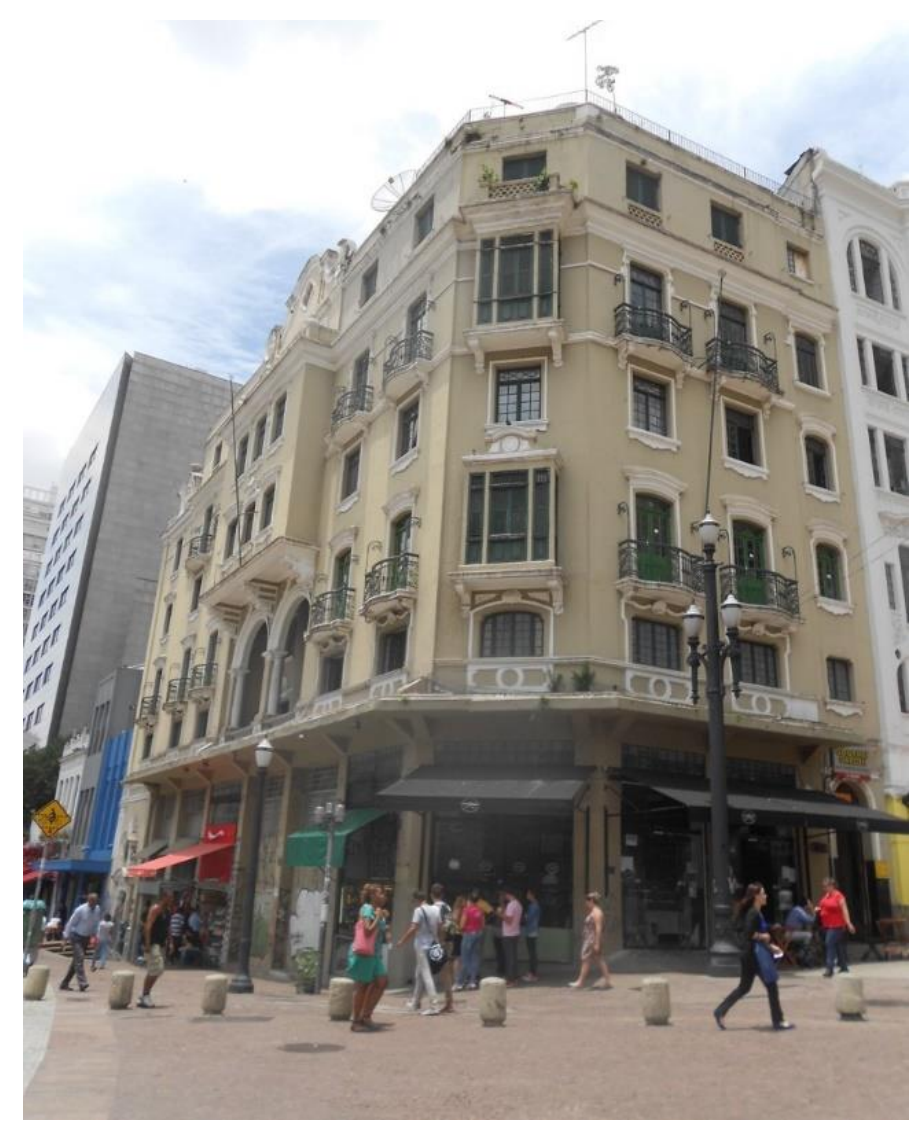

Figure 10. Facade of the Building "Baraúna"

Source: Author's Photo, 2015.

Edifice Antique Number 12, 1926 (Figures 11, 12 and 13)

In 1926, drawings of the plants, sections and facade were presented for "project of a house to be built on Avenida São João, 12" (current 102-104), for the owner Mr. Dr. José Pucci, by the builder Luiz Asson. When analyzing the drawings, it is observed that the building was intended for commercial use and services.

The lot, resulting from the expropriations, has a small front but great depth. The building has five floors more ground floor, and occupies the whole lot, with a small area for lighting and ventilation on the back. Access to the upper and lower floors is from the left side. From the overstore to the other floors, the stairs are located on a distribution hall at the back of the building, marking the vertical circulation. On the ground floor, besides the access, there is a commercial establishment.

The eclectic composition of the facade seems that it is one single opening axis. The facade is divided horizontally on the body with the overstore and the first floor, and the three upper floors. On a lower row, the openings are wide, with bodyguard in artistic iron. The windows are made of glass and wood, and composing the set, the overstore has arch straight while the first floor has segmental arch. Finishing on the sides two false pilasters with decorated capitals, 
that supports the architrave in segmental arch completing this theme.

In the second floor, a balcony with three consoles and balustrade bodyguard stand out discreetly from the alignment. The third and fourth floors also have large openings with artistic iron bodyguards. Two false pilasters appear finishing up these three floors on the sides, with the rounded architrave on the corners.

The crowning has entablement based on five corbels, and the brick border balustrade has at the center a kind of pediment, in the form of a round arch. On it, there is a false tympanum with decoration in stucco.

The building maintains its decorative architectural characteristics from the time of its construction; however, its conservation is average. Probably the edifice was coated with scraped mortar (artificial stone), but currently it is painted with colorful ink.

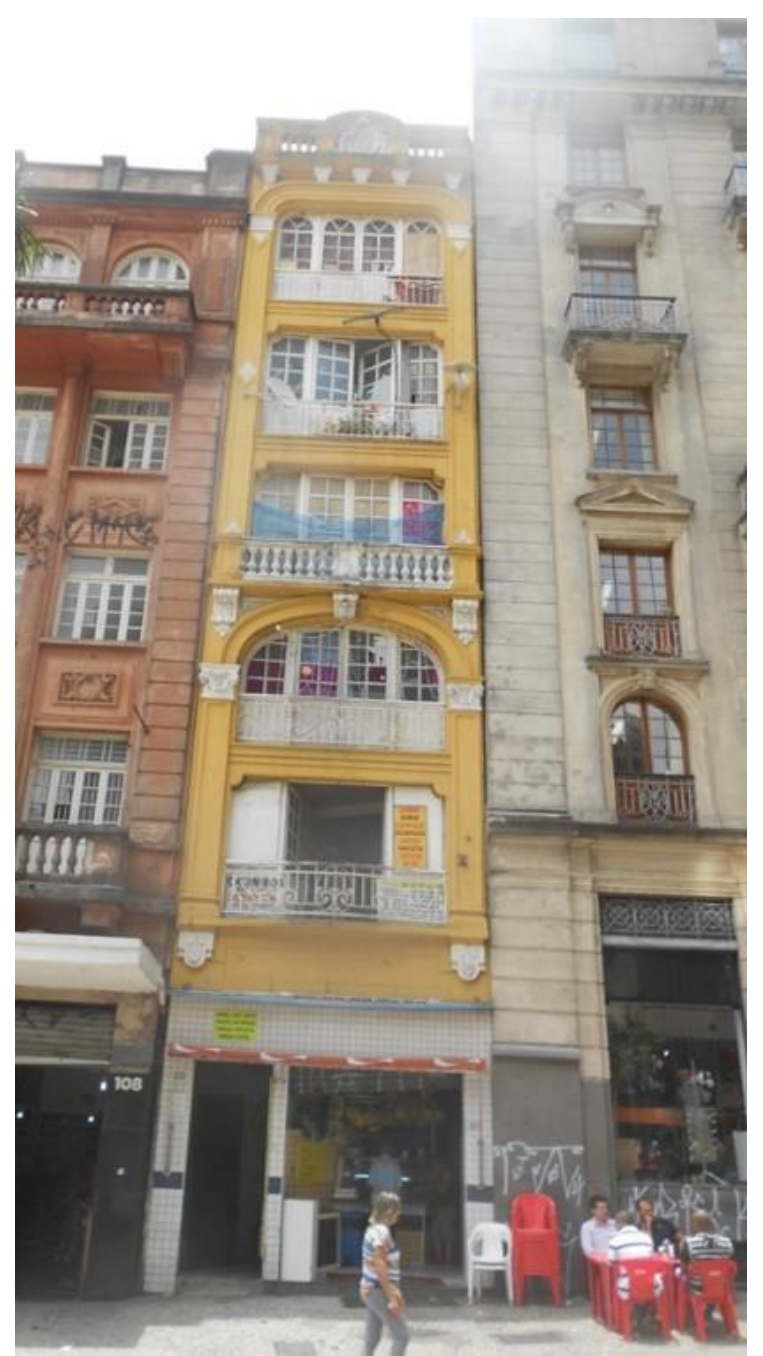

Figure 11. Facade of Edifice Antique Number 12 Source: Author's Photo, 2015. 


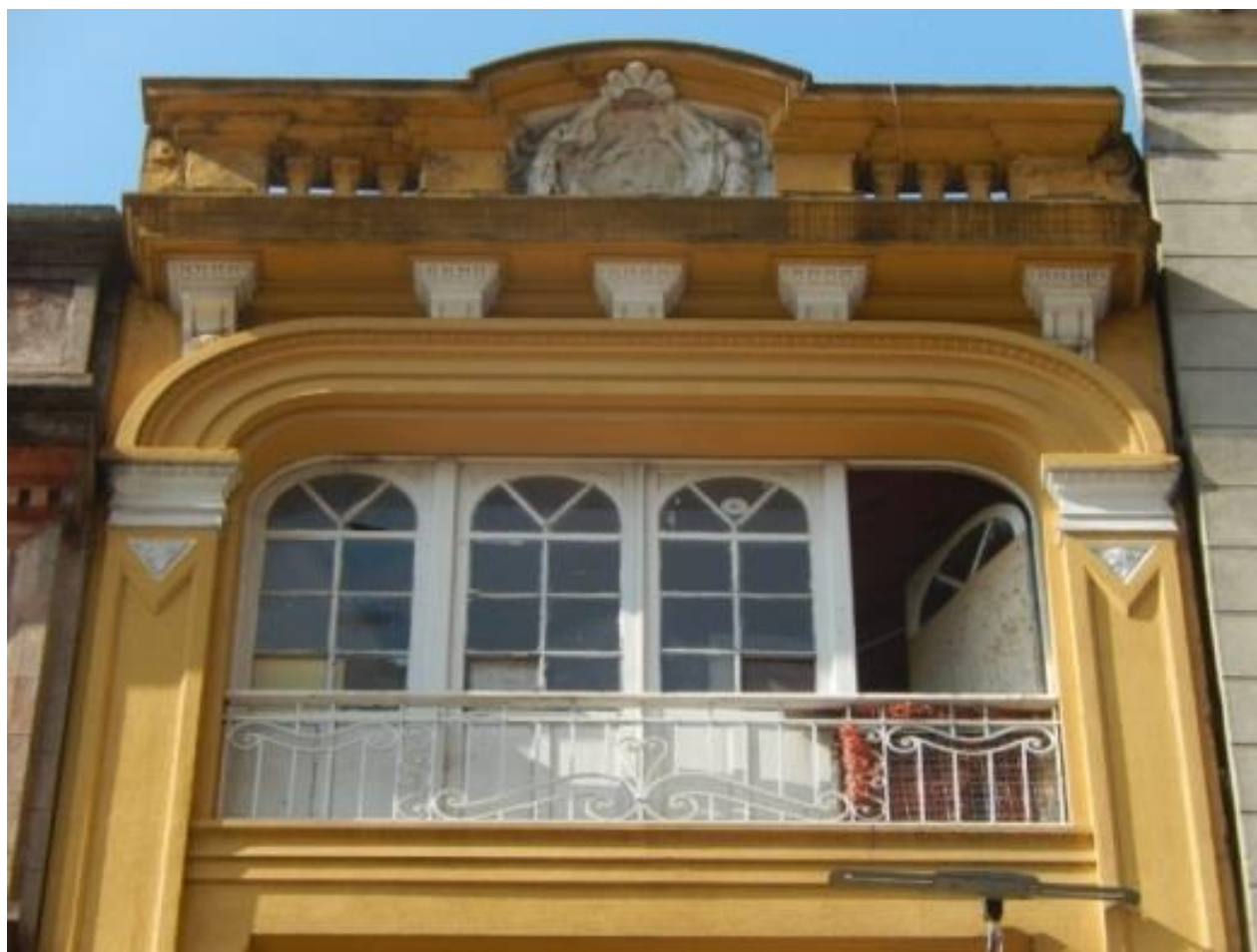

Figure 12. Detail of Façade

Source: Author's Photo, 2016.

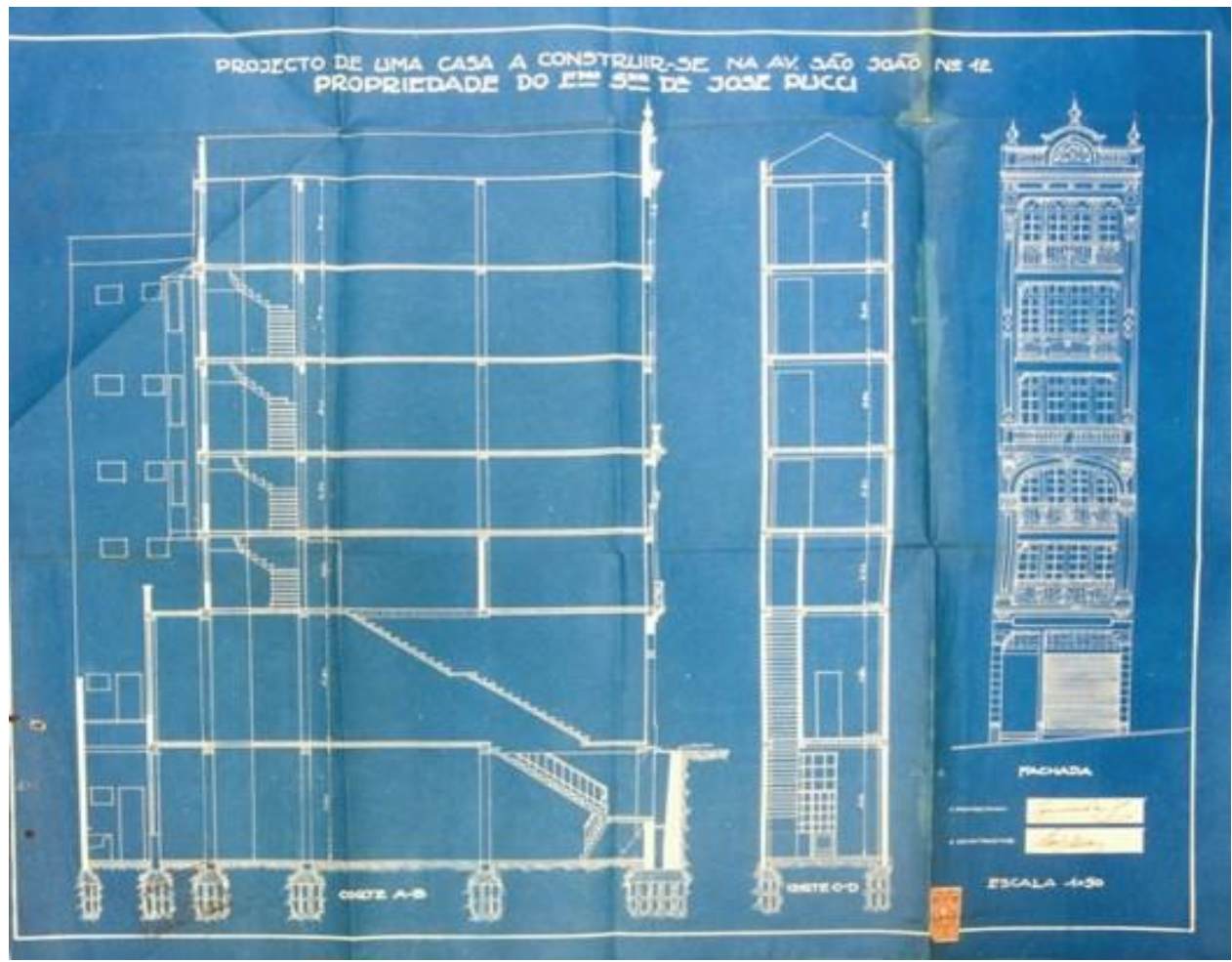

Figure 13. Drawings of the Plants and Sections of the Building "Antique Number 12" Source: Original drawings, 1926, from the Arquivo Histórico São Paulo - AHSP.

Edifício Antigo Número 12A, 1936 (Figure 14, 15 and 16) 
The building Number 12 (current 108) that concludes the section of this study, was built in 1936, showing that the "boulevard" model adopted as a modern urban work in the city of São Paulo in the period of the First Brazilian Republic (18901930) was still relevant. The company that built this edifice is A. Salfati \& M. Buchignani.

As the last lot of this block, the lot is ample on the back, with a small front to the Avenida São João, which allowed an interesting project. The building has a commercial ground floor plus four floors; and the access to the upper floors is on the left side of anyone looking at the building.

The eclectic facade, according to the drawings and iconographic documents, of the basement always had a wide door occupying practically the whole front. A balcony with corbel and balustrade bodyguard distinguishes the body made up of three floors with three aligned arch straight openings axis. Two fake plain columns with simple capitals between the openings emphasize the verticality of this body.

A new balcony with corbel and balustrade bodyguard identifies the fourth floor that holds the three openings, but both with round arch. A single entablature and the brick border make the crowning. Two pilasters on the sides, interrupted between the third and fourth floors, finish off the building.

The outside coating is in grated mortar (artificial stone), while the frames are made of glass and wood. The building is characterized with small damages, but with medium conservation.

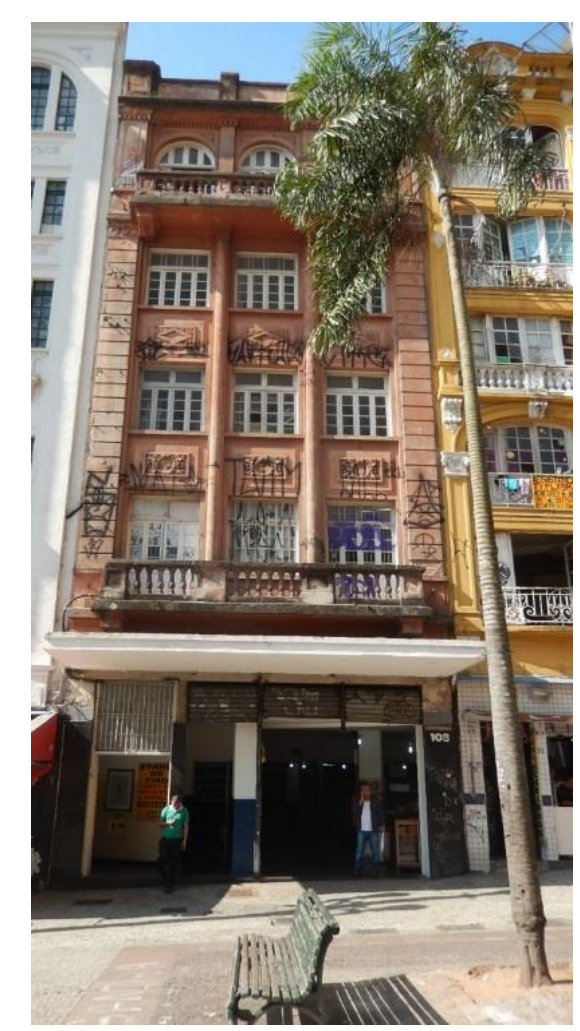

Figure 14. Facade of the Edifice Antique Number $12 \mathrm{~A}$

Source: Author's Photo, 2015. 


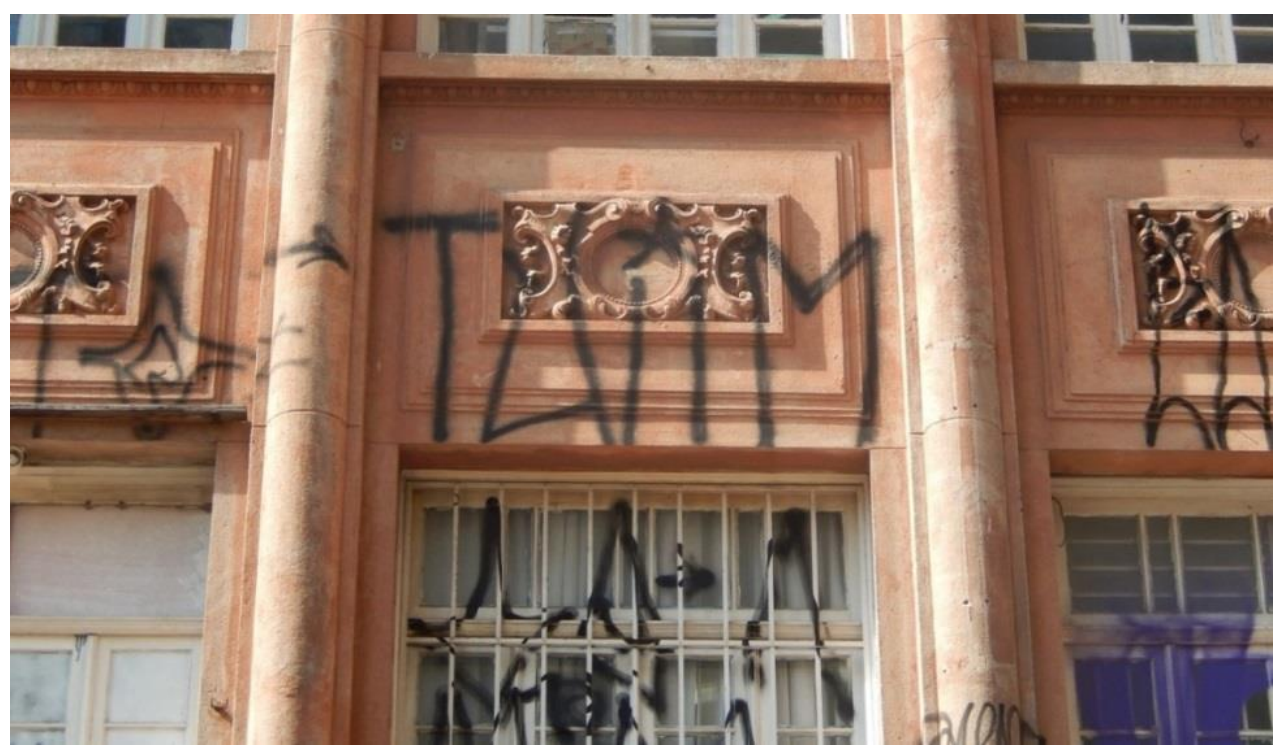

Figure 15. Detail of Facade Highlighting the Decoration Source: Author's Photo, 2016.

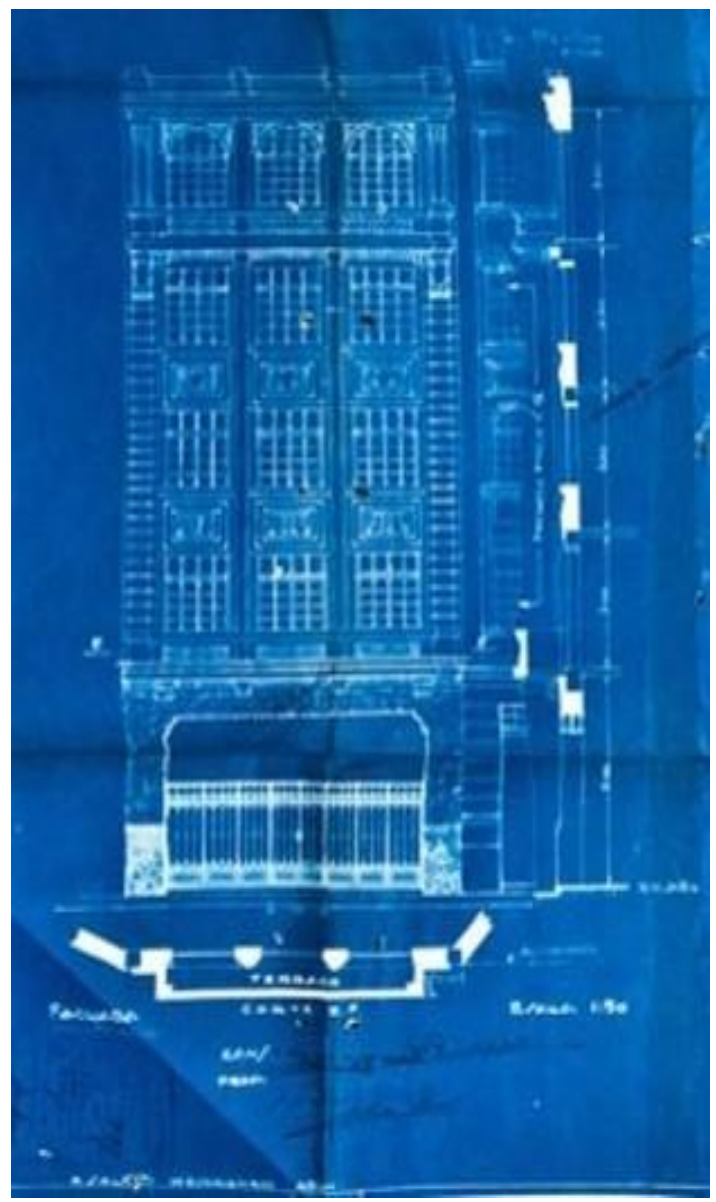

Figure 16. Drawing of the Facade of the Edifice "Barauna"

Source: Original drawings, 1936, from the Arquivo Histórico São Paulo - AHSP.

At long last, some of the edifices built during the period of the study (1890- 
1930) were revealed and described. The urban landscape impact of São Paulo at the beginning of the decade of 1930 was caused by the new architecture implemented following the new alignment proposed by the widening street law. In a way, this created a space with eclectic architecture that lasted practically through the period between the two World Wars.

\section{The 'Boom' of Civil Construction}

The architectural projects resulting from the enlargement of Street São João pointed to the first boom of civil construction in the city of São Paulo. To make this demand viable, the properties located on the even side of the road were expropriated, demolished, and rebuilt in the new alignment. These new constructions intended to meet the new building standards, according to the Law published in 1912 already cited.

Some other facts contributed to this, such as the lever of the domestic economy through the coffee industry, also known as the richness of the "green gold". Population growth, mainly from immigration, certainly stimulated the construction. Opportunities for professionals like capomaestri, architects and engineers to work in the city grew significantly. Two technical-professional schools were installed on the known neighborhood Brás in 1911, which contributed to the specialization of the workforce. New technical offices, such as Ramos de Azevedo and Cia, started to operate.

In the opinion of the architect Hugo Segawa, ${ }^{16}$ the consequent urban expansion into a new area of the city began with the construction of the Viaduto do Chá, the bridge inaugurated in 1894. The opening of Antônio Prado Square in 1904 to 1906 was the first urban work of "modernization" that proposed the expropriation of an area, the demolition of existing buildings to open squares, streets, and new constructions following new pre-established patterns, which we call as model "blockbusters" made in the city. The observation made by Caio Prado $\mathrm{Jr}^{17}$ complements what is studied here:

"The pauliceia of narrow streets and modest houses, which fit in the triangle, existed until the first Great War - it was the seat of an agricultural São Paulo, of coffee, which reigned a strong territorial aristocracy: people who were more proud of the farm than of the city, and when thought about the city, it was Paris."

16. Hugo Massaki Segawa, Prelúdio da Metrópole (São Paulo: Ateliê Editorial, 2004), 21.

17. Ernani Silva Bruno, História e tradições da cidade de São Paulo (São Paulo: VOL I, II, III. José Olympio, 1954), 1315-1316. "A paulicéia de ruas estreitas e casas modestas, que cabia no triângulo, existiu até a primeira Grande Guerra - era a sede de um São Paulo agrícola, do café, que imperava uma forte aristocracia territorial: gente que tinha mais orgulho da fazenda que da cidade, e quando pensava em cidade era Paris". 


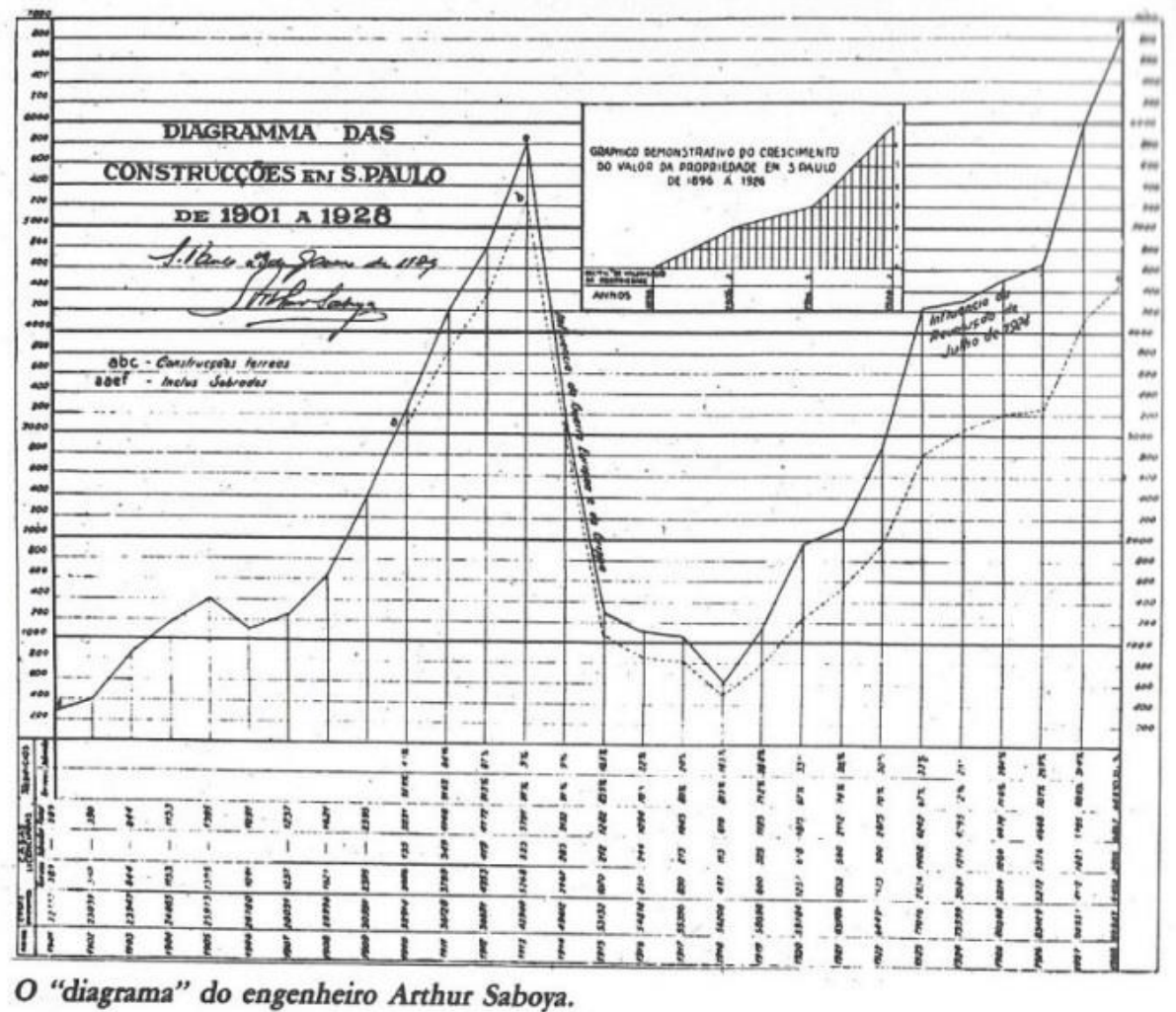

Figure 17. Chart Drawn by the Engineer Arthur Saboya

Source: Revista Illustrada Brasileira (sic.), n. 109, 1929. Also published in Lemos, 1989, 164.

During World War I, recalling that building materials were imported, there was much difficulty in marketing the products. A graph drawn by engineer Arthur Saboya (Figure 17) indicates the number of buildings in the city from 1901. This chart shows a sharp upward curve of growth in the number of buildings, which was abruptly cut off in 1914, only resuming with the end of the war in $1918 .^{18}$

The architecture built at this time is called "eclectic," but often the miscellany is so large that it is confused with a pastiche. The city looked like a patchwork for the researcher Maria Cecília Naclério Homem. As commented Alessandro D'Atri on his visit to the city in 1925: "A lot of Paris, a bit of modern Rome, some impressions of London and Brussels, the straight lines of Turin and, in popular neighborhoods, much of Naples."19

The cartographic base that presents the land situation in 1930, coincides with the current cadaster of the lots, blocks and fiscal sectors used by the municipality. We adopted this base because it is representative of the end of the study period. In the plan Sara Brasil detail (Figure 1), 1930, is noted the five buildings of this article with the respective dates of construction. In the section of the whole

18. Lemos, "A cidade dos fazendeiros,” text published in Emanoel Araújo, O café (São Paulo: Banco Real/ABN AMRO, 2000), 102.

19. Alessandro D'Atri, L'Etat de São Paulo et le renouvelement économique de l'Europe (Paris: V. Allard, Chantelard e Cie, 1926), 189. In: Maria Cecília Naclério Homem, O prédio Martinelli, a ascensão do imigrante e a verticalização de São Paulo (São Paulo: Projeto, 1984). 
survey (Antônio Prado Square - Avenida Ipiranga), there are sixteen buildings on the even side of the twenty existing in this fragment that were built in the period of this study resulting from the opening works of Avenue São João. A traveler, who Ernani Silva Bruno ${ }^{20}$ quotes, said:

"Those who walk the streets, who look and shout, buy and sell, feel that there lies the center of a modern, international metropolis of a city of commerce and industry." And he adds: "In these narrow streets, tall buildings, men run and jostle as in any capital of Europe."

Concerning the materials and constructive techniques used, the architect Benedito Lima de Toledo ${ }^{21}$ synthesizes with great consistency São Paulo into three types: the taipa (mud wall); the brick; and the concrete. In this study was verified that the old pylon mud wall (taipa de pilão) was in fact replaced by the bricks masonry. The introduction of concrete into buildings allowed higher heights, added after the use of elevators. As for the building typology, the influence is certainly European.

The studies done by the sociologist Lucila Herrmann ${ }^{22}$ in 1935 about the development of São Paulo by the radial of coffee analyze the change of the south axis "Caminho do Mar" to the northwest "present Avenida São João". In this work, she presents important information such as the values taken in the expropriations on Avenue São João. From 1911 to 1913, the years were the largest expropriated area, and the value of the square meter was the highest. Coincidentally, in the period of the First World War were the years that least expropriations. The value of the square meter from 1914 to 1916 fell sharply, then between 1917 and 1919 rose again. There was a resumption of expropriations from 1920 to 1922, including an increase in the value of the square meter. Between 1923 and 1925, the value of the square meter came to reach the lowest price. Again, a major investment was made between 1926 and 1928.

The study shows in Table (B), which lists the amounts spent on expropriations in various areas of the city, between 1926 and 1930, Avenue São João was a record holder of expenditures in downtown and Anhangabaú Avenue. The two tables $(C$ and $D)$ illustrate the rental value and the square meter of the property on Avenida São João and Caminho do Mar, while chart (E) shows the average rental values. With these informations in hands when comparing values between the stretches of two radial: São João-Água Branca and Caminho do Mar, it is explicit the appreciation that São João Avenue had in the section of this study.

Finally, we turn to the hypothesis of the displacement of the east axis of the São Paulo occupation by the Tamanduateí River. To a new axis west of the

20. Bruno, História e tradições da cidade de São Paulo, 1954, 1319.

21. Benedito Lima de Toledo, São Paulo: três cidades em um século (São Paulo: Duas Cidades, 1981).

22. Lucila Herrmann, Estudo do desenvolvimento de S. Paulo através da análise de uma radial: a estrada do café (1935) (São Paulo: Revista do Arquivo Municipal, XCIX, 1944); Regina Helena Vieira Santos, Rua São João: o Boulevard paulistano da Primeira República (São Paulo: Doutorado FAU-USP, 2017). On Herrmann studies were presented some charts that are available also on Santos, 2017. 
centre, that developed as consequence of the coffee economy after the second half of the 19th century, was circulating and propitiating the development of the urbanization of the city to this direction, including with the great valorization land.

Comparing the hypothesis above to the one raised by the architect José Geraldo Simões Jr., ${ }^{23}$ we come to the following conclusions. He proposed that the inversion of polarity in the urban structure of the city took three moments: the first from 1554 to 1867 facing the Tamanduateí River (east); the second from 1867 to 1892 around the railways and the Luz Station (north); the third from 1892 to 1917 with the works of improvements in the meadow of Riverside Anhangabaú (west).

We conclude that the option of the enlargement of Street São João affirmed the territorial occupation for the western direction of the primitive site and consequently the real estate valorization, allied to the architecture of the new buildings. It was not by chance that the change of focus of the city occurred: from funds to Anhangabaú, this stream became the front. The construction of the Municipal Theater, inaugurated in 1911, was an anchor project for all this valorization. Also inspiring appreciation for the artists who participated on the important Modern Art Week of $1922^{24}$ as Anita Mafaltti (Tropical, 1917), Tarsila do Amaral e Zina Aita which recorded the park of Anhangabaú, among others, the writers Oswald de Andrade and Mario de Andrade (Figure 18).

Another source of inspiration was the cinema. The Movie Poster "São Paulo, a sinfonia da metrópole," 25 produced in 1929 by Rex Film, anticipates the process of verticalization that decades later the city would pass. According to Nicolau Sevcenko:

"Monumental verticality becomes the main sign of metropolization. The Martinelli Building incorporated into the heart of the São Paulo capital the mystical-concrete vision of the skyscraper. The poster of the film São Paulo, the symphony of the metropolis extracts vertical icons the athletic genius of strength. Already the polish Podsadeck has a tragic vision of the modern City." 26

23. José Geraldo Simões Junior, Anhangabaú: história e urbanismo (São Paulo: Senac/ Imprensa Oficial do Estado de São Paulo, 2004).

24. Jorge Ricca Jr., Anhangabaú: construção e Memória (São Paulo: Mestrado FAU/USP, 2003), 160-162.

25. Inspired by the silent film, black and white, produced in 1927, Berlin: symphony of the metropolis, original German title: Berlin: Die Sinfonie der Großstadt under the direction of Walter Ruttmann. A documentary about the routine of Berlin of his day, with the workers leaving early to work in factories, ending the day in the bustling nightlife in Berlin of the 1920s. In the flow of a day, the multi-faceted society of the time, that is, from poverty and the life of a worker, to wealth and luxury. The directors Rodolfo Lustig and Adalberto Kemeny produced the documentary released in 1929: São Paulo, the symphony of the metropolis, the idea is to portray the São Paulo society of the 1920s. The "setting" of this film is often Rua/São João Avenue. Both contextualize the urban environment after the First World War The city of São Paulo, "a formidable and cyclopical metropolis", "growing dizzyingly", "the noise that lends the city the environment of the great metropolis", in the silent film the seller of pots, on foot, beating them. "Life on the streets. Shaking. Tumult. Disaster. And the city boasts of its service of public assistance". "The angel ... and the sun descends upon the earth its final rays, greeted by the magnificent offering of the symphonia of the afternoon ...", so ends the film.

26. Nicolau Sevcenko, Orfeu extático na metrópole. São Paulo sociedade e cultura nos 
Many saw with optimism the embryo of the verticalization process that would begin in the Paulicéia, ${ }^{27}$ but some were already dazzled by the catastrophe that would come. Years after the inauguration of the Martinelli building, at the opening of Cine Metro also in the Avenue São João, the poet Guilherme de Almeida ${ }^{28}$ wrote:

"A new axis sweeps the city. Stretched, straight, between two symbolic mountains of our greatness - the Jaraguá, historical mountain that God made; and the Martinelli, a modern mountain that men have made - the Avenida São João, magnetic, is calling itself urban life and the cinema too. "29

Almeida's words elucidate the fascination, the wonder that was Avenida São João to the city.
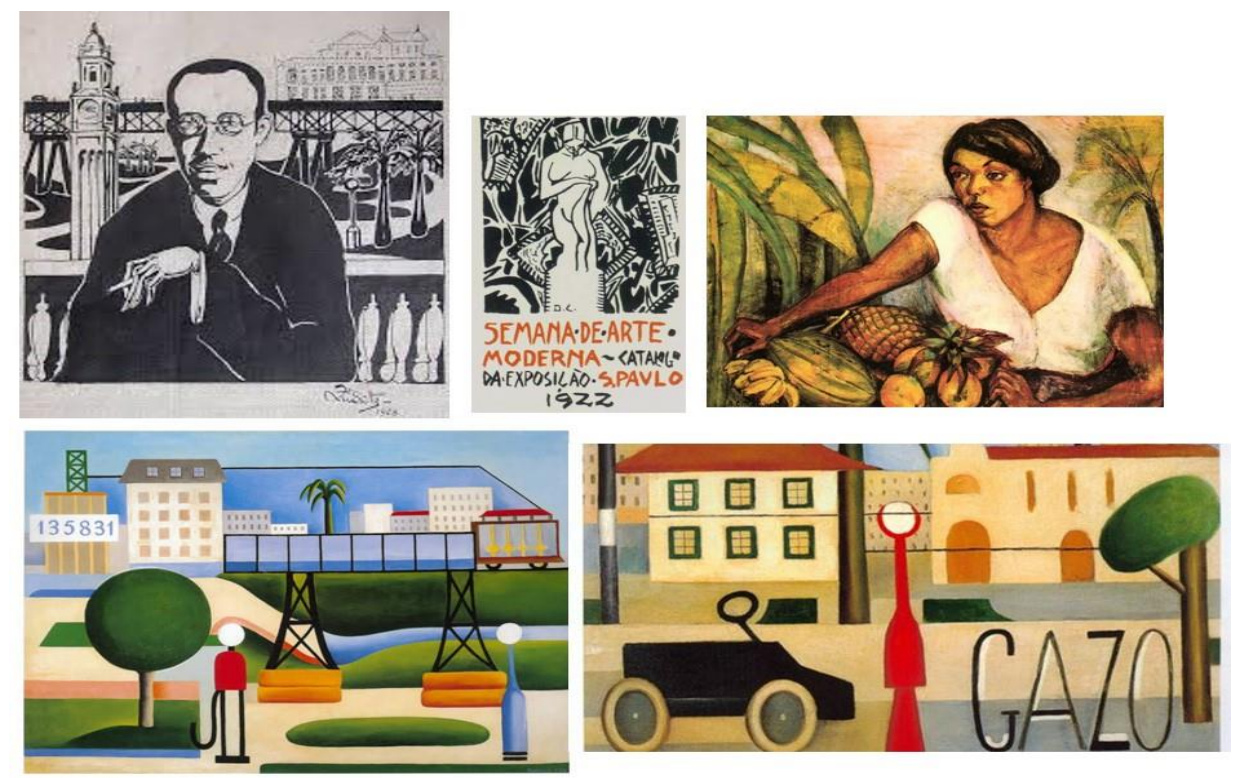

Figure 18. Paintings from Modern Art in São Paulo, 1920's

Source: Picture of Mario de Andrade, by the artist Zina Aita, 1923 (IEB-USP); catalog of Semana de Arte 1922; Tropical, by the artist Anita Malfatti, 1917 (Pinacoteca SP); São Paulo 135831, and GAZO by artist Tarsila do Amaral, 1924 (Pinacoteca SP).

frementes anos 20 (São Paulo: Companhia das Letras, 2014), 176-177. "A verticalidade monumental se torna o principal signo da metropolização. O Prédio Martinelli incorporou ao coração da capital paulista a visão místico-concreta do arranha-céu. O cartaz do filme São Paulo, a sinfonia da metrópole extraí ícones verticais o gênio atlético da pujança. Já o polonês Podsadeck tem uma visão trágica da Cidade moderna".

27. Paulicéia is an old way of referring to the city of São Paulo.

28. Guilherme de Almeida (1890, Campinas-SP; 1969, São Paulo-SP). Graduated in 1912 in the Faculty of Law, was poet, translator, playwright and essayist. He founded with Oswald de Andrade, Sergio Milliet, Mario de Andrade among others the magazine Klaxon, the way of spreading the modernist ideas.

29. "Um novo eixo vara a cidade. Esticada, reta, entre duas montanhas simbólicas da nossa grandeza - o Jaraguá, montanha histórica que Deus fez; e o Martinelli, montanha moderna que os homens fizeram - a Avenida São João, magnética, vai chamando a si a vida urbana e o cinema também”. Published in the newspaper: O Estado de São Paulo of 15/3/1938. 


\section{Conclusions}

The hypothesis studied in the doctor's research does not discuss the best or worst urban plan proposed, or the eclectic architecture of the buildings. The focus is on the physical impact on the city at the time of the decision to extend São João Street. The even side, which had all primitive buildings demolished and rebuilt in the new alignment, generated a new eclectic environment. The odd side, as observed in the documents, also followed the path of the transformations. The carriage way was widened with a central separator area and lanes for public transport on rails. In short, the relevance of this boulevard to the city of São Paulo in the period of the First Republic (1889-1930) is evident (Figure 19).

In conclusion with all the information consulted, the option for the enlargement of Rua São João, through various ways of seeing, was a natural consequence of the occupation of the territory as a reflection of the economy. The historian teacher Beatriz Piccolotto Siqueira Bueno noted that this was the successful "Operation Urban" at the time.

The 'urban plan' was superficial, resulting in punctual laws, such as the 'enlargement of Avenida São João', without compromise with a design for the city or proposals for the facades. This plan was made without scheduling water supply, treatment of sewage, expansion of public transport lines, as well as the provision of electricity. Furthermore, it disregarded housing programs for the growing population in the city.

After the period covered by this work, already in the middle of the twentieth century, Avenida São João was still a road of great reference in the capital city of the State of São Paulo. The area was highly valued in the real estate market as a destination of reference for the cultural leisure (mainly theatres and cinemas) besides "meeting place" of the paulistanos and visitors of the city (many hotels). The verticalization process was already consolidated, but the route remained emblematic in the metropolis.

This work, besides contributing a small part to the urban history of São Paulo, is a part of the methodology to develop architectural and urban conservation and restoration projects. It deals with a very small fragment with its eclectic architectural patrimony that has survived the sudden transformations of a great metropole, which must be preserved.

The methodology adopted in the research can also be used by preservation agencies to instruct the pulled down (preservation) process, as well as to develop safeguard proposals. This is thus a work that can propitiate a partnership between the faculties of architecture and urbanism and the municipalities. 


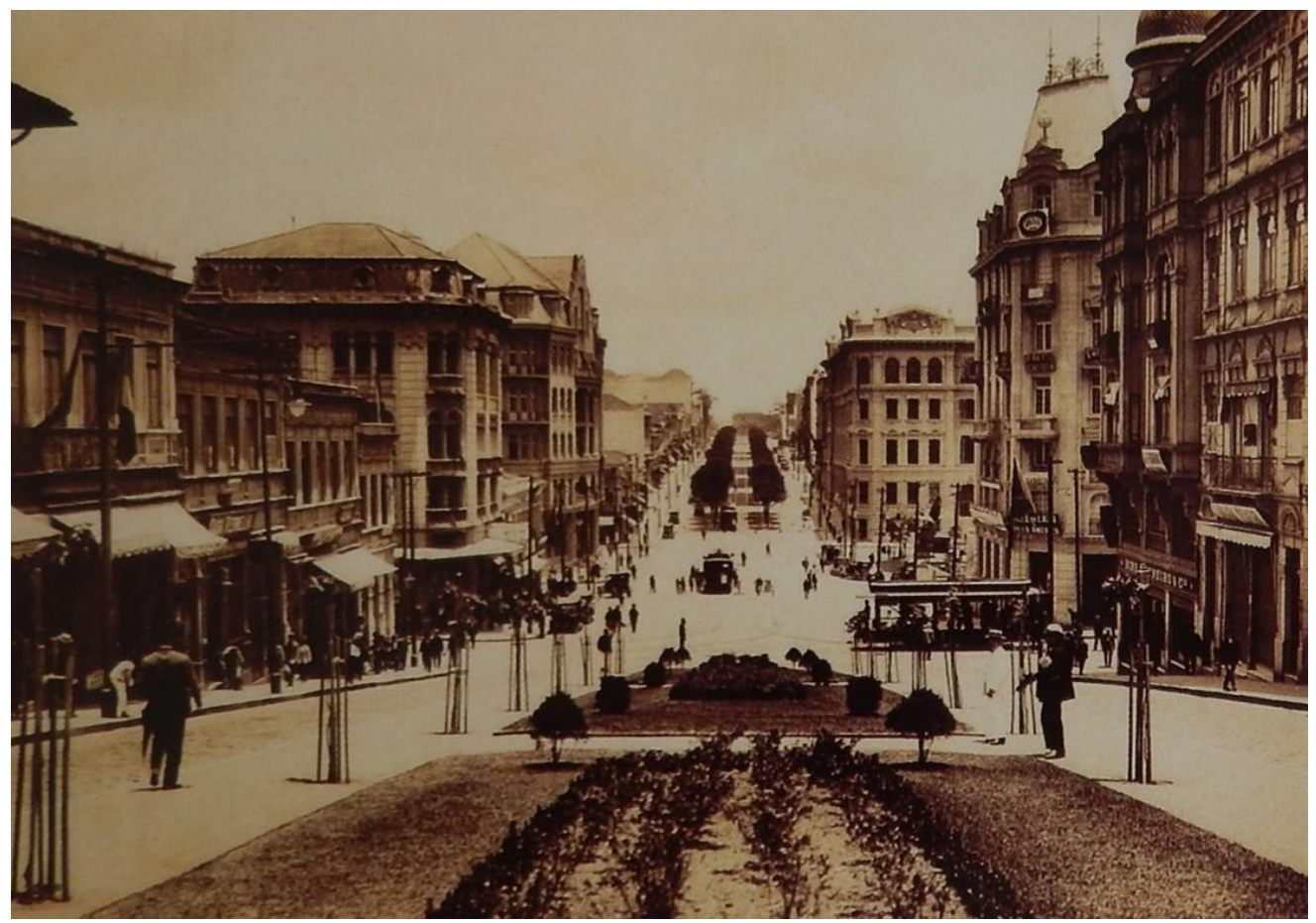

Figure 19. Post Card of Avenida São João, c.1922

Source: Lemos in Araujo, 2000, 103

\section{Bibliography}

AHSP. Inventário: Salas de cinema em São Paulo: 1895-1929 [Inventory: Cinema in São Paulo: 1895-1929.

Araújo, Emanoel. O café [The coffee]. São Paulo: Banco Real/ABN AMRO, 2000.

Arquivo Histórico São Paulo-AHSP-Documents. Coleção Obras Particulares [Private Works Collection].

Bruno, Ernani Silva. História e tradições da cidade de São Paulo [History and traditions of the city of São Paulo]. São Paulo: VOL I, II, III. José Olympio, 1954.

D'Atri, Alessandro. L'Etat de São Paulo et le renouvelement économique de l'Europe [The State of São Paulo and the economic renewal of Europe]. Paris: V. Allard, Chantelard e Cie, 1926.

Herrmann, Lucila. Estudo do desenvolvimento de S. Paulo através da análise de uma radial: a estrada do café (1935) [Study of the development of S. Paulo through the analysis of a radial: the coffee road (1935)]. São Paulo: Revista do Arquivo Municipal, XCIX, 1944.

Homem, Maria Cecília Naclério. O prédio Martinelli, a ascensão do imigrante e a verticalização de São Paulo [The Martinelli building, the rise of the immigrant and the verticalization of São Paulo]. São Paulo: Projeto, 1984.

Lemos, Carlos A. C. A República ensina a morar (melhor) [The Republic teaches to live (better)]. São Paulo: HUCITEC, 1999.

. Alvenaria Burguesa [Bourgeois masonry]. São Paulo: Nobel, 1989.

. Cozinhas, etc. [Kitchens, etc.]. São Paulo: Perspectiva, 1976.

Mello, Joana. Ricardo Severo: da arqueologia portuguesa à arquitetura brasileira [Ricardo Severo: From Portuguese Archeology to Brazilian Architecture]. São Paulo: 
Annablume-Fapesp, 2007.

Pinheiro, Maria Lúcia Bressan. Neocolonial, Modernismo e Preservação do Patrimônio no Debate Cultural dos Anos 1920 no Brasil [Neocolonial, Modernism and Preservation of Heritage in the Cultural Debate of the 1920s in Brazil]. São Paulo: EDUSP/Fapesp, 2011.

Reis Filho, Nestor Goulart. São Paulo Vila Cidade Metrópole [Sao Paulo Town and Village Metropolis]. São Paulo: Takano Editora Gráfica, 2004.

Ricca Jr., Jorge. Anhangabaú: construção e Memória [Anhangabaú: construction and Memory]. São Paulo: Mestrado FAU/USP, 2003.

Santos, Regina Helena Vieira. Rua São João: o Boulevard paulistano da Primeira República [São João Street: the Paulista Boulevard of the First Republic]. São Paulo: Doutorado FAU-USP, 2017.

São Paulo (SP). Secretaria Municipal de Cultura. Departamento do Patrimônio Histórico. IGEPAC-SP: Inventário geral do patrimônio artístico e cultural de São Paulo (Banco de dados) [General inventory of the artistic and cultural patrimony of São Paulo (Database)]. São Paulo: DPH, 2012.

Segawa, Hugo Massaki. Prelúdio da Metrópole [Prelude of the Metropolis]. São Paulo: Ateliê Editorial, 2004.

Sevcenko, Nicolau. Orfeu extático na metrópole. São Paulo sociedade e cultura nos frementes anos 20 [Orpheus ecstatic in the metropolis. São Paulo society and culture in the early twenties]. São Paulo: Companhia das Letras, 2014.

Simões Junior, José Geraldo. Anhangabaú: história e urbanismo [Anhangabaú: history and urbanism]. São Paulo: Senac/ Imprensa Oficial do Estado de São Paulo, 2004.

Toledo, Benedito Lima de. São Paulo: três cidades em um século [São Paulo: three cities in a century]. São Paulo: Duas Cidades, 1981. 